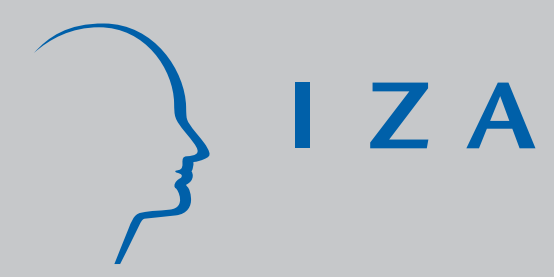

IZA DP No. 2981

Assessing the Importance of Male and Female Part-Time Work for the Gender Earnings Gap in Britain

Karen Mumford

Peter N. Smith

August 2007 


\title{
Assessing the Importance of Male and Female Part-Time Work for the Gender Earnings Gap in Britain
}

\author{
Karen Mumford \\ University of York and IZA
}

\section{Peter N. Smith}

University of York

\author{
Discussion Paper No. 2981 \\ August 2007 \\ IZA \\ P.O. Box 7240 \\ 53072 Bonn \\ Germany \\ Phone: +49-228-3894-0 \\ Fax: +49-228-3894-180 \\ E-mail: iza@iza.org
}

\begin{abstract}
Any opinions expressed here are those of the author(s) and not those of the institute. Research disseminated by IZA may include views on policy, but the institute itself takes no institutional policy positions.

The Institute for the Study of Labor (IZA) in Bonn is a local and virtual international research center and a place of communication between science, politics and business. IZA is an independent nonprofit company supported by Deutsche Post World Net. The center is associated with the University of Bonn and offers a stimulating research environment through its research networks, research support, and visitors and doctoral programs. IZA engages in (i) original and internationally competitive research in all fields of labor economics, (ii) development of policy concepts, and (iii) dissemination of research results and concepts to the interested public.
\end{abstract}

IZA Discussion Papers often represent preliminary work and are circulated to encourage discussion. Citation of such a paper should account for its provisional character. A revised version may be available directly from the author. 


\section{ABSTRACT}

\section{Assessing the Importance of Male and Female Part-Time Work for the Gender Earnings Gap in Britain*}

This study examines the role of individual characteristics, occupation, industry, region, and workplace characteristics in accounting for differences in hourly earnings between men and women in full and part-time jobs in Britain. A four-way gender-working time split (male fulltimers, male part-timers, female full-timers and female part-timers) is considered, and allowance is explicitly made for the possibility of both workplace and occupational segregation across each group. Individual and workplace characteristics are shown to explain much of the earnings gaps examined. Within gender groups, the striking difference between full and part-time employees is that full-timers work in higher paying occupations than do part-timers. Also, female occupational segregation makes a significant contribution to the earnings gap between male and female part-time employees but not for full-time workers. A further new result is that female workplace segregation contributes significantly to the full/part time earnings gap of both males and females. Part-time employees work in more feminised workplaces and their earnings are lower. By contrast, female occupational segregation has little impact on the full-time/part-time earnings gap of either males or females. There remains, moreover, a substantial residual gender effect between male and female employees.

JEL Classification: J3, J7

Keywords: gender earnings, wage gap, part-time, fixed effects, segregation

Corresponding author:

Karen Mumford

Department of Economics and Related Studies

University of York

Heslington York YO10 5DD

United Kingdom

E-mail:kam9@york.ac.uk

\footnotetext{
* We thank the WERS04 sponsors - the Department of Trade and Industry, the Economic and Social Research Council, the Advisory, Conciliation and Arbitration Service and the Policy Studies Institute for allowing access to the data. They are not responsible for any of the findings or claims made in the paper. We are also grateful for helpful advice and comments from participants of the DTI Employment Relations Seminar Series (especially Grant Fitzner, Carmen Alpin, Barbara Kersley and John McQueeney), and the 2007 WPEG conference.
} 


\section{Introduction}

The earnings gap between part-time female and full-time male employees in Britain has been remarkably persistent over the last four decades despite the introduction of equal pay legislation in the 1970s. ${ }^{1}$ This issue has recently been placed firmly at the forefront of policy concern with the Prime Minister establishing a Women and Work Commission in 2004 to seek ways to tackle the gap. The Commission found that, whilst the causes of the gender earnings gap were complex and interrelated, intrinsic amongst them was occupational segregation, lack of qualifications, discrimination, and fewer job opportunities for women wanting to combine market employment with non-market family responsibilities. ${ }^{2}$ In April 2007, Ruth Kelly (the Minister for Women) announced that the Government had responded to the Commission's findings with the introduction of the new Equality $\mathrm{Act}^{3}$ and a range of policies predominantly targeted at increasing the occupation choices of women (via skill acquisition and broadening attitudes) and increasing their ability to cope with family and work commitments simultaneously. ${ }^{4}$

There is clearly a perception that occupational choice, hours worked and the nature of the workplace are all important factors in the gender earnings gap. There is, however, very little empirical work that attempts to separately analyse these possible determinants. In particular, part-time male employees are usually ignored, leading to the possibility that the relationship between earnings and gender is confounded with the relationship between earnings and occupation or working part-time.

This study provides a robust assessment of the importance of a number of determinants of the gaps in earnings between the four groups of employees who make up the workforce; males and females who work full and part-time. The analysis considers the contribution of the individual employee characteristics as well as occupations, industry, region and other workplace characteristics. These results give

\footnotetext{
1 "Women working part-time earn an average of 40 per cent less per hour than men working full-time, about the same as when the Equal Pay Act was introduced 30 years ago.” Julie Mellor, Chair of the Equal Opportunities Commission, 2004, as cited on 1/6/2007 at www.workingbalance.co.uk/sections 2 “... women are crowded into a narrow range of lower-paying occupations, which do not make the best use of their skills...The problem is multi-faceted and deep-rooted and the response must be wideranging and aimed at all its drivers.” Women and Work Commission, 2006. as cited on 1/6/2007 at www.womenandequalityunit.gov.uk/women_work_commission).

${ }^{3}$ The Equality Act 2006 amends the Sex Discrimination Act and came into effect on 6 April 2007.

${ }^{4}$ Ruth Kelly, Minister for Women. Foreword in Towards a Fairer Future, Implementing the Women and Work Commission Recommendations, April 2007. Department for Communities and Local Government.
} 
rise to an analysis of the importance of segregation of employees into particular workplaces and occupations and their contribution to observed earnings gaps.

The literature on gender wage inequality is well established (see surveys by Altonji and Blank, 1999; Weichselbaumer and Winter-Ebman, 2005). Discussion of recent results for Britain is provided in Joshi and Paci (1998), Mumford and Smith (2005) and Manning and Robinson (2004). Whilst there is dispersion in the findings of these studies, it is generally concluded that a substantial and persistent earnings gap exists between male and female employees.

The gender earnings gap is commonly explained by a component due to differences in individual characteristics associated with productivity and a residual. This residual (or unexplained component) is sometimes called the pure gender effect. According to Harkness (1996) about half of the gap in Britain prior to 1992 was unexplained by differences in individual characteristics rising to some 60 per cent in 1992. Following the work of Bergmann (1971) and Groshen (1991) a further component of the gap associated with the segregation of women into particular occupations has been shown to be important. Analogously, segregation at the workplace level may also make an important contribution to explaining the gap. There is an increasing body of work on the gender pay gap which seeks to exploit linked evidence on both individual worker characteristics and those of their workplaces as an additional feature which might explain the earnings gap. ${ }^{5}$

There is also a small literature that considers the potential for different gender pay gaps between part-time and full-time employees in the UK. These studies typically concentrate only on females (Tam, 1997; Manning and Petrongolo, 2006), males (O’Dorchai, Plasman and Riycx, 2007) or a comparison between part-time or full-time women with full-time men (Anderson et al, 2004). A common result in these studies is the attribution of much of the gap to the segregation of part-time workers into lower wage occupations and a large remaining unexplained earning gap between full-time and part-time employees (O’Dorchai, Plasman and Riycx, 2007).

Hirsch (2005) examined the part-time wage differential across genders for the United States in 2002 and showed that workers in part-time employment appeared to have accumulated less human capital over their lives. There was also an important

\footnotetext{
${ }^{5}$ Holzer and Neumark, 2000; Abowd et al, 2001; Drolet, 2002; Bayard et al, 2003; Anderson et al, 2004; Manning and Petrongolo, 2004; Mumford and Smith, 2005; Reilly et al, 2006.
} 
contribution in Hirsch's results from occupations as a determinant of the fulltime/part-time gap for both females and males.

Manning and Petrongolo (2004) included data from WERS 1998 in their study of the pay gap in Britain; they found that firm specific effects had little impact on the part-time full-time pay gap for women. Rather, they concluded that the relatively lower skills required for jobs considered to be suitable as part-time occupations for women were associated with lower wages. Manning and Petrongolo (2006) further found that female part-time employees earned considerably less than their full-time female counterparts, and the majority of this gap was explained by occupational segregation. They did not include males in this later study.

Further recent British studies support this view. Connolly and Gregory (2007) showed that substantially fewer skills were required for part-time compared with fulltime female employment. They did not include males in their study. Paull (2006) found that women were much more likely than men to take on part-time employment in response to the introduction of children into the family. This is perhaps not a surprising result; indeed, the phenomenon (and a range of hypothetical explanations) has been commonly discussed across a broad spectrum of literature (Fagan and Hebson 2004; page 5). Paull (2006) provided empirical evidence of the extent of the effect. These studies used either the New Earnings Survey or the British Household Panel Survey. Neither of these data sets included information on the workplace for the employee.

In this study, we investigate the gender gap for both part-time and full-time employees in Britain and the associated full-time/part-time earnings gap. We consider a four-way gender-working time split (male full-timers, male part-timers, female fulltimers and female part-timers), and explicitly allow for the possibility of both occupational and workplace female segregation. This allows for calculation and decomposition of five bilateral earnings gaps (male full-timers/male part-timers, female full-timers/female part-timers, male full-timers/female full-timers, male parttimers/female part-timers and male full-timers/female part-timers). We believe that this is the first time that such a complete study has been undertaken specifically including part-time male employees as a separate category for comparison in Britain, and especially using data from WERS04. 


\section{Data}

The data used in this study are drawn from the British Workplace Employee Relations Survey 2004 (WERS04) ${ }^{6}$. WERS04 is a nationally representative survey of workplaces with 5 or more employees ${ }^{7}$. (A workplace comprises the activities of a single employer at a single set of premises.) Face-to-face interviews for WERS04 were conducted with a senior manager (with day-to-day responsibility for employee relations). At those workplaces responding to the manager survey, a questionnaire was presented to 25 randomly selected employees (in workplaces with more than 5 employees) or to all the employees (in workplaces with fewer than 26 employees). The entire surveying process resulted in 2,295 completed workplace surveys, with 22,451 completed employee questionnaires from 1,733 of these workplaces.

WERS04 is a stratified random sample, and larger workplaces and some industries are over-represented. The data have been weighted throughout the paper to allow for the complex survey design and thus represent the sampling population ${ }^{8}$. All of the empirical results that follow use workplace and employee sampling weights when possible.

WERS04 and its predecessors have been used to analyze diverse research questions (Millward et al. 2004), but we are not aware of any research using these data to examine the gender earnings gap explicitly including male part-time employees in Britain. Retaining only those individuals who have complete information for the variables used in the analyses below leaves us with over 20,000 employees from more that 1,700 workplaces.

\section{Earnings and the earning gaps}

\subsection{Measuring the earnings gaps}

Summary statistics for the samples of primary interest to this study (full-time male and female, and part-time male and female, employees) are presented in Table $1 .^{9}$ The

\footnotetext{
${ }^{6}$ Department of Trade and Industry (2006). Workplace Employee Relations Survey: Cross-Section, 2004 (computer file). $5^{\text {th }}$ ed. Colchester: The Data Archive (distributor). SN: 5294.

${ }^{7}$ The industries excluded from the survey were agriculture, hunting and forestry; fishing; mining and quarrying; private households with employed persons; and extra-territorial organisations and bodies.

${ }^{8}$ The advantages from using weighted complex survey design data is discussed at length in Deaton (1998) and by the suppliers of the WERS data series (see footnote above). When weighted accordingly, the data are representative of all workplaces with 5 or more employees, located in Great Britain, and engaged in activities within sectors D (Manufacturing) to O (Other Community, Social and Personal Services) of the Standard Industrial Classification (SIC) 2003. The data, suitably weighted, are therefore also representative of all employees within these workplaces.

${ }^{9}$ Full definitions of the variables and further sample statistics are available in the appendix.
} 
measure of earnings used is average hourly earnings for each employee. This is calculated by dividing the employee's gross (before tax and other deductions) weekly wages by the hours they usually work each week (including any overtime and extra hours). Whilst usual hours worked is a continuous measure, the survey responses for gross weekly wages are banded in the data set. There are 14 bands and the midpoints of these bands are used. Any employees showing an hourly rate of pay below $£ 1$ or above $£ 100$ are excluded from the dataset. On this measure, female hourly earnings are on average 20.4 log per cent (or log wage points) below male average hourly earnings.

This measure of the gender earnings gap is consistent with measures provided by other studies for Britain, although these measures do vary with the data used. For example, Harkness (1996, page 3) reported an earnings gap of 41 per cent for 1973; and 29 per cent in 1993 (using data from the Family Expenditure Survey). Manning and Robinson (2004, page 175) using data from the British Household Panel Survey, also found a fall in the earnings gap from a gap of 34 log per cent in the early 1990s to 29 log per cent in the late 1990s. Mumford and Smith (2005) found a gap of 26.5 log wage points using WERS 1998 data.

A part-time employee is defined to be working 30 or fewer hours per week, a common definition used in the UK (Manning and Petrongolo, 2004). According to this definition, 29.3 per cent of the workforce is employed part-time: 12.2 per cent of the men and 44.5 per cent of the women.

The mean earnings gap between full-time and part-time employees in Britain is 22.2 log per cent. This study is specifically concerned with comparing male and female full-time and part-time employees, implying that there are five earnings gaps to consider (Table 1): the male full-time to female full-time gap, which is 14 log per cent in terms of mean log hourly earnings; the male full-time to male part-time gap, which is $11.7 \log$ per cent ${ }^{10}$; the female full-time to female part-time gap, which is $17.9 \log$ per cent ${ }^{11}$; the male part-time to female part-time gap, which is 20.1 log per cent; and the male full-time to female part-time gap, which is 31.8 log per cent (see also Figure 1).

\footnotetext{
${ }^{10}$ Hirsch (2005) employed the Current Population Survey (CPS) and found a 21.9 log per cent gap between female full and part-time workers and a 46.4 log per cent gap for men in the US in 2002.

${ }^{11}$ Manning and Petrongolo (2004; page 16) using data from WERS 1998 in their study of the pay gap in Britain, found a wage gap between part-time and full-time females of 24.5 log per cent.
} 


\subsection{The determinants of earnings}

\subsubsection{Individual characteristics}

Most authors have adopted the human capital model as the theoretical basis for the earnings function (an extensive recent survey was provided Chiswick, 2003). This approach will also be used here. At the individual employee level, it is assumed that wages increase with measures of accumulated skills such as education, work experience, and training.

WERS04 provides information as to the highest level of education the individual has received across a range of educational categories. Close to 30 percent of the full-time work force (male or female) has a degree or postgraduate qualification, for part-time males this drops to 25 per cent, whilst only 16 per cent of part-time women do (Table 1). It is more common for part-time employees to have no post-age 16 qualifications (80 per cent of part-time males compared to 58 per cent of full-time males; and 65 per cent of part-time females compared to 54 per cent of full-time females). Those with no recognised qualifications also make up a substantial proportion of employees, especially amongst the full-time males and the part-time females.

Measures of work experience are usually assumed to be positively related to wages via the ability to acquire skills over the time period the employee has spent working. Typically, studies do not have data on the history of actual lifetime work experience across firms for individuals. Instead proxies are provided, the most common of which is potential experience: the age of the individual minus years spent in education. This may lead to an underestimate of the relationship between work experience and earnings if the individual was not actually employed during substantial parts of their life (such as the long-term unemployed or mothers who have taken time out of the labour force to care for their children, Swaffield (2007)). WERS04 also does not have information on actual experience over working life; potential experience (age minus education and infant years) is instead used and the results need to interpreted with this caveat in mind.

The length of the time the employee has spent in employer-provided training in the previous year is also included in the dataset; this measure of training is expected to be positively related to wages (Hashimoto, 1981; Almeida-Santos and Mumford, 2005). 
The earnings function is augmented with the inclusion of further categories of explanatory variables capturing individual employee characteristics such as demographic variables (which may constrain an individual's choice of jobs including the presence of dependent children, marital status, ethnic identification, and physical disability); individual job characteristics (being on a fixed term contract, and union membership); and occupation.

Considering the demographic variables in more detail, there are three dependent child measures according to the age of the youngest child: preschool (0-4 years), primary school (5-11) and secondary school (12-18). Just over a third of British employees have at least one dependent child in these age ranges, most commonly amongst full-time men and part-time women. Only 5.5 per cent of fulltime women are employed with a preschool child (compared to 15 per cent of fulltime men and 14 per cent of part-time women). However, full-time women are just as likely to have an older dependent child (12-18 years) as are full-time men. There is a greater tendency for part-time women to be married (72 per cent relative to 61 per cent of the full-timers). For men this difference is very dramatic: full-time men are five times more likely to be married than are part-men (70 per cent relative to 14 per cent). There are more male employees who consider themselves to be of a non-white ethnic background than female employees, especially amongst part-time female employees; perhaps reflecting different cultural attitudes to females participating in the labour market. Finally, a substantial proportion of the workforce has an ongoing physical disability; this is more common amongst men and, in particular, for part-time men.

Considering the individual job characteristics, some 3 per cent of employees are hired on fixed term contracts, reflecting a more insecure employment future. Parttime men are almost twice as likely to be employed in this way. Current job tenure (uncompleted spells) is on average 5 years (5.3 for men and 4.8 for women), not surprisingly it is lowest for part-time men. Current job tenure is expected to be positively related to wages primarily because it reflects a successful match between employee and employer (Mumford and Smith, 2004). Returns to current job length have often been found to be very small and the major action with this variable in the literature appears to be capturing the wage gains associated with changing jobs (Manning and Robinson, 2004). 
Union membership has declined dramatically in Britain since the 1970s. Nevertheless, in 2004 it was still substantial at around a third of all full-time employees (and, at the least a quarter of part-time male employees) representing a potentially major source of bargaining power. The union may provide a voice mechanism for the individual thereby leading to fewer quits, longer tenure and higher wages (Freeman and Medoff, 1984). Unions may also, however, provide a range of other services to their members, which could increase relative job satisfaction and lower the wage rate. A positive relationship between union membership and earnings is expected.

Amongst the occupation categories, women are less likely to be managers, professionals or craftsmen. They are much more likely to be employed in the technical, clerical, personal services, and sales occupations. A concentration in sales or personal services is common amongst part-time employees, as is being unskilled. This is true for male and female part-time workers. Occupational choice, at an individual level, is often treated in much the same way as educational outcome since they both reflect a range of variables, especially individual ability and opportunity (Filer, 1986).

Occupational choice may also be constrained. We seek to capture this latter effect by including measures of female segregation at the occupational level. The measure of occupational segregation used is the proportion of females in the occupation, computed from the number of females in any given occupation and calculated from the responses to the employee questionnaires. This is a direct measure of femaleness. The influence of the occupation on the earnings gap may be wider than that captured by this measure. Female segregation is common at the occupational level; 62 per cent of women work in occupations with a proportionately high female workforce (64 per cent of part-time women and 61 per cent of full-time women), in contrast, only 41 per cent of full-time men do.

\subsubsection{Workplace characteristics}

A range of workplace characteristics are included in the analyses, these can be considered in clusters: industrial sector; physical and market conditions; employment conditions; and industrial relations measures.

The standard twelve industrial codes are used to designate industrial sector. The largest employing industries in Britain are manufacturing; wholesale and retail 
sales; other business services; and health. Each of these industries hires approximately 15 per cent of the workforce. The numbers of men and women in wholesale and retail trades and in other business services are relatively similar, with men concentrating slightly more in the former and women in the latter. Part-time employment is more common in the wholesale and retail trades, hotels, education, and the health sectors. Full-time men are much more likely to work in the manufacturing sector, however, as are part-time women in the health sector.

Physical and market conditions are captured by: workplace age, workplace size, if the firm has multiple UK work sites, if the workplace is foreign controlled, and if the workplace is facing increasing market demand. On average, workplaces are 44 years old and have 49 employees. Given hours worked, males tend to work in older workplaces but not significantly so. Females tend to work in larger workplaces, especially full-time females. The majority of workplaces are owned by firms who operate multiple workplaces (76 per cent), whilst 14 per cent are foreign controlled. Males are more likely to work in these workplaces, as are full-time employees. A little over a third of the workplaces were facing increasing market demand for their output (more so for part-time males).

The measures of employment conditions include: an index of six family friendly practices; an index of the extent of employer and employee interaction; if employees believe salary is based on age or years of experience; and if employees believe salary is based on job grade.

The index of six family friendly work practices ranges from zero to six depending on how many of the following practices are available: paternity leave; maternity leave; home working; job sharing; child care; and/or paid family leave. Budd and Mumford (2003), using WERS98, find positive payoffs in terms of workplace performance and lower levels of employee absenteeism for workplaces with higher values of this index. A positive relationship is also expected between the practices and earnings.

The index of the extent of employer and employee interaction at the workplace ranges from 0 to 5 . It is the sum of five separate indicator variables: if the worker has a lot of discretion over their work; if any of the workforce operate in quality circles; if any of the workforce operate in formal teams; if targets are consulted with employees; and if a system of briefing employees exists. 
The summary statistics reveal quite different levels of these measures of employment conditions. In each case, however, females are more likely to say they are available to them as are full-time employees (although often this difference is not substantial).

Finally, amongst the workplace characteristics, an index of industrial relations (IR) measures at the workplace is calculated. This IR index ranges from 0 to 3 . It is the sum of three separate indicator variables each set equal to one if: there are union members at the workplace; there is a human resources representative at the workplace; or there is a collective grievance procedure present. The final industrial relation measure is whether or not the workplace has a formal written equal opportunity policy. Males and females report similar averages for the presence of these measures, with the exception of a written equal opportunity policy where females (full-time or parttime) are significantly more likely to report it present in their workplace than are their male counterparts.

Analagous to the measure of female occupational segregation discussed above, a measure of workplace segregation (the percentage of females in the workplace, calculated from the responses to the employee questionnaires) is also included. Female segregation at the workplace level is more extensive than at the occupational level; 70 per cent of women work in workplaces with a proportionately high female workforce (76 per cent of part-time women and 65 per cent of full-time women), in contrast, only 32 per cent of full-time men do.

To reiterate, much of the difference between full-time and part-time employees comes from the characteristics of the female part-time workforce. These women have more experience, less recent training, fewer degrees, are less likely to be from a non-white ethnic background, and have longer current job tenure. They are much more likely to have a young dependent child and to work as clerks, in sales or in personal services. They are concentrated in the wholesale and retail trades, education, and the health sectors. They are also very likely to work in female dominated workplaces and occupations.

In contrast, part-time males tend to be younger, single, on a fixed term contract, not be a union member, and be employed in sales or unskilled occupations. Compared to male full-time employees they are also much more likely to work in a female dominated workplace or occupation. 


\section{Estimation}

\subsection{Models and methods}

The earnings equations that are estimated are semi-logarithmic and versions of:

$$
W_{i}=\alpha+X_{i} \beta+Z_{k} \gamma+\varepsilon_{i}
$$

where $W_{i}$ is the natural $\log$ of the earnings of individual $i ; X_{i}$ is a vector of regressors measuring a range of individual characteristics; $Z_{k}$ a set of workplace characteristics and $\varepsilon_{i}$ is a residual term. Model A contains only the individual characteristics. Model B expands the set of individual characteristics to include the occupational indicator variables as fixed occupation effects.

The role of the workplace is handled in two ways. First, this happens through the inclusion of a workplace-specific fixed effect to create Model C (ie the $Z_{k}$ are fixed workplace effects and the estimates $\hat{\beta}$ are therefore within workplace estimates of the impact of the individual characteristics). In Model $\mathrm{D}$ the $Z_{k}$ are extended to include the industry in which the workplace operates which is identified by a set of binary variables. This model also contains a set of workplace characteristics descriptive of the size, age, region of location, and nature of the workplace along with measures of a range of human resource management and other practices. Finally in Model E the individual and workplace characterisitics are extended to include measures of female workplace and occupational segregation. All of the models are estimated using least squares applying appropriate weights reflecting the design of the dataset. $^{12}$

We estimate all models separately for each of the groups of employees, male and female, full-time and part-time. Pooling of models for males and females is a common approach (see Bayard et al, 2003, for example). We take the view that models for part-time and full-time employees may be more likely to produce different parameters than those for all employees. This is borne out in the results shown below.

\footnotetext{
${ }^{12}$ Robustness of the estimation results is of clear concern. The nature of the earnings data in WERS04 presents an issue for the construction of the earnings series in the analyses presented here. As noted above, the earnings data in WERS04 is banded. As Stewart (1983) discusses, it is possible, in principle, that this banding may affect the properties of the ordinary least squares estimates of the earnings function that we estimate. Comparison of the least squares estimates presented here with interval estimates confirms that are very similar. We therefore confine our analysis to the least squares estimates whilst also providing the interval regression estimates of the various models in an appendix available upon request.
} 


\subsection{Estimation results}

The estimates of the various earnings models for each of the groups of employees are presented in Tables 2 to 5 . These are the estimates of models A - E for full and parttime males and full and part-time females. The standard errors reported are robust to heteroskedasticity in the residuals of an unknown form. All estimates employ complex survey weights when possible.

Estimates of the basic human capital model (Model A) which contains only individual characteristics are presented in Table $2^{13}$. All of the estimates demonstrate the standard feature of the human capital model that earnings are increasing in potential experience but at a decreasing rate. This results from a positive coefficient on the level of potential experience and a small negative parameter on the squared level of potential experience. Training and educational achievement likewise are found to be positively related to earnings. There are, however, significant differences between the parameters for the various groups.

The estimates show significant differences in returns to some educational qualifications (which are lower for part-time than full-time males for higher levels of educational achievement). The returns to lower level educational qualifications are estimated to be significantly lower for part-time than full-time females. By contrast, the returns to training are significantly greater for part-time employees, especially for males.

Having children is significantly positively associated with earnings for fulltime men and negatively for full-time females. The largest and most significant of these differences is for the association between earnings and having children aged between 12 and 18. This extends to younger children aged 5-11 for part-time females. The estimates for part-time men are less well determined but positive. There is a positive association between being married or partnered for males which is higher for part-time males.

There is generally significant evidence of lower earnings for disabled and nonwhite employees. These effects are largest for part-time male employees and insignificant and small for part-time female employees. Finally, there is strong

\footnotetext{
${ }^{13}$ These earnings function estimates explain between 23.1 per cent and 38 per cent of the variation in log earnings. The lower figure applies to the estimates for the part-time employees where we might expect the unmodelled heterogeneity of the employees concerned to be higher than for full-time employees. There is also a smaller sample of observations for part-time employees, especially for parttime males which could be expected to reduce the model fit.
} 
evidence of a positive return to current job tenure and, for all but full-time male employees, a positive impact from being a member of a trade union.

Turning to the extended models, the results for estimates of Model B are presented in Table 3. This model augments the basic individual characteristics with information on individual occupations. As discussed above, a number of authors have identified an important role for occupations in explaining both the male/female and full-time/part-time earnings gaps. The lower panel of estimates shows that occupation is significantly associated with earnings. We omit the clerical occupational group and all parameters are therefore estimates of the difference from earnings in clerical occupations associated with any particular occupation. These are estimated to be positive for technical, professional and managerial occupations and negative for the remainder. The differences in returns from the various occupations can be seen to be larger for part-time compared with full-time employees, substantially so for the additional earnings associated with managerial and professional occupations.

The estimates in Table 3 also provide a view of the role of individual characteristics within occupations. Comparison of the estimates on these variables with those for Model A shows that these are qualitatively similar. One difference is that the return for being a member of a trade union is positive also for full-time male employees within occupations.

A further comparison which can be made, given the nature of the WERS04 dataset, is to control for the workplace of the worker as well as the occupation. The most general way to do this is by treating the workplace as a workplace-specific fixed effect. The estimates of Model $\mathrm{C}$ therefore measure the impact of the individual within occupations and workplaces. The individual estimates are little changed from those for Model B and are available in the appendix.

In Model $\mathrm{D}$ we use characteristics of the workplace to provide a set of determinants of earnings in addition to individual worker characteristics and occupation fixed effects (Table 4). These workplace variables are descriptive of the nature of the workplace, the industry and region in which it operates and of its human resource management policies and practices. Increased workplace size and whether the workplace is foreign owned raise earnings significantly for full-time male and female employees. Increased presence of family friendly practices in the workplace is associated with significantly higher earnings for all but part-time male employees. Likewise, the index measuring the extent of interaction between employees in the 
workplace has a positive and significant impact on earnings for all but part-time males. In this sense higher quality workplaces appear to reward individuals more highly ${ }^{14}$. However, the presence of a trade union in the workplace appears not to have an impact on earnings over and above whether the worker concerned is a union member. Union membership continues to be positively associated with earnings for part-timers but not for full-timers. The estimates also show that, when compared with the manufacturing sector, the hotels sector pays the lowest having allowed for individual characteristics of employees and their occupations. Male full-time earnings are highest in financial services whilst for female full and male part-timers utilities is the highest earning sector. Construction is the highest paying sector for part-time female employees. Earnings in London and, to a lesser extent, the South East are higher than in the East Midlands for all four groups of employees. In the case of part-time female employees the difference is 23 log percentage points more than in any other region and 13 log percentage points more for part-time males. The regional gaps are not as pronounced for full-time employees. For full-time female employees earnings are significantly lower in the North East and Wales than in other regions.

\section{Decomposing the gender pay gap}

The estimates we have for the four groups of employees allow us to examine a number of earnings gaps. The approach we adopt to apportion the gap in the mean earnings of any two groups is that discussed in Oaxaca and Ransom (1994). In general, the decomposition of the mean earnings gap between groups of employees $a$ and $b$ is calculated as:

$$
\bar{W}_{a}-\bar{W}_{b}=\left\{\left(\bar{X}_{a}-\bar{X}_{b}\right) \hat{\beta}_{a}+\left(\bar{Z}_{a}-\bar{Z}_{b}\right) \hat{\gamma}_{a}\right\}+\left\{\bar{X}_{b}\left(\hat{\beta}_{a}-\hat{\beta}_{b}\right)+\bar{Z}_{b}\left(\hat{\gamma}_{a}-\hat{\gamma}_{b}\right)\right\}
$$

for the model described in equation (1) above. In this calculation $\left(\bar{X}_{a}-\bar{X}_{b}\right) \hat{\beta}_{a}$ captures the impact of the difference in the individual characteristics weighted by the parameters from the model for group $a$; $\left(\bar{Z}_{a}-\bar{Z}_{b}\right) \hat{\gamma}_{a}$ captures the impact of the difference in the characteristics of the workplaces where groups $a, b$ work, again weighted by the parameters from the model for group $a$; and

\footnotetext{
${ }^{14}$ The presence of an equal opportunities policy has no significant impact in these results. The point estimates of the effect suggest higher earnings for part-time males but this effect is very small as well as statistically insignificant. This confirms the analysis of Mumford and Smith (2005) on WERS98 who found no significant impact on the earnings gap between all male and all female employees.
} 
$\left\{\bar{Z}_{b}\left(\hat{\beta}_{a}-\hat{\beta}_{b}\right)+\bar{Z}_{b}\left(\hat{\gamma}_{a}-\hat{\gamma}_{b}\right)\right\}$ is the remaining unexplained gap. The decompositions are presented in Figures 1 to 5.

Beginning with Model A in Figure 1, the central core of the figure lays out the four sub-samples of concern (male part-time, female part-time, female full-time and male full-time). Each total bilateral earnings gap is presented next to an arrow indicating the direction of the comparison. Thus, the earnings gap between male fulltime employees and male part-time employees is 11.7 log per cent: Male full-time employees earn 11.7 log per cent more on average than do male part-time employees. This earnings gap can be decomposed into the component due to differences in the mean values of their individual characteristics which make up 11.5 log percentage points, and an unexplained component of 0.2 log percentage points; the two components summing to the earnings gap of 11.7 log per cent. The contribution of the differences in the individual characteristics is evaluated using the parameters from the model for the higher earnings group ( $a$ in equation (2), full time males in this case). The unexplained component results from differences in the parameters for the two groups evaluated at the mean vales of the individual characteristics for the lower wage group ( $b$ in equation (2), part time males here).

It would seem in this simple model (which only considers individual characteristics) that the higher hourly earnings of full-time males over part-time males merely reflect the relatively more productive characteristics the former group possesses (or, at least, characteristics associated with higher hourly pay). In contrast, female full-time employees earn 17.9 log per cent more than do female part-time employees (the arrows always point from the higher earning group to the lower), with $7.1 \mathrm{log}$ percentage points being due to their having more productive characteristics on average and 10.7 log percentage points due to characteristics which are positively associated with earnings being rewarded at a lower rate for part-time women. The model does not explain why they are being rewarded differently (hence the term 'unexplained').

Comparing male full-timers with female full-timers, the earnings gap is 14 log per cent in favour of the males. Of this gap, according to Model A, 2.4 log percentage points is due to this group of females having less productive characteristics than the corresponding males. The remaining 11.5 log percentage points (clearly the major 
component of the gap) is unexplained and is due to the female characteristics being rewarded at a lower rate than are those of males. The results for male part-timers relative to female part-timers are even more disparate. These males earn 20.1 log per cent more than the females. This gap is decomposed into the individual characteristics component of $-14.1 \log$ percentage points and the residual unexplained $34.2 \mathrm{log}$ percentage points or, in other words, part-time males have less productive characteristics than part-time females and they are over-rewarded for these characteristics.

As discussed previously, Model A only includes measures of the individual characteristics, Model B adds occupation controls. Results for the decompositions for Model B in Figure 2 reveal that differences in occupation are associated with a relatively large component of the earnings gap. This is particular true when comparing full and part-time employees. Part-time employment appears to be concentrated in low paid occupations, especially so for part-time females. Finally, there is a relatively small negative effect of occupation for full-time males compared to full-time females (implying that full-time women are more likely to be in higher paying occupations than are full-time men).

The results of introducing workplace specific fixed effects into Model B to create Model C can be seen by comparing Figures 2 and 3. This reveals little impact on the results for full-time males relative to full-time females: these males on average work in lower paying occupations but in better paying workplaces. The results are very different, however, when we compare part-time and full-time employees within each gender group. Once we allow for the positive additional payments associated with the occupations full-time employees are concentrated in, a strong positive impact of their workplaces is also revealed. Full-time employees tend to work in higher paid occupations and in higher paying workplaces relative to part-time employees. Finally, male part-timers can now be seen to be working in higher paying occupations but in low paying workplaces relative to female part-time employees.

The decomposition results from including all of the workplace-related variables in Model D are presented in Figure 4. These show that working in higher paying industries makes up a substantial component of the earnings gap between male full and part-time employees and between male part-time and female part-time employees. In general, women appear to work in lower paid industries than do men, especially part-time females. Including a wider range of workplace variables in Model 
D has a small impact on the results with the unexplained earnings gap between female full and part-time employees reduced to less than 1 log per cent. The overall impact of the workplace variables is that men, both full and part-time, work in workplaces with characteristics associated with lower earnings relative to the workplaces of their female counterparts. However, full-time employees benefit from the workplace more than part timers of the same gender. The geographical region in which the workplace is situated also explains a small proportion of the gaps between full and part-time employees of the same gender. A gap of more than 1 log per cent in hourly earnings between female full and part time employees is due to full timers working in higher paying regions according to Figure 4.

In Figures 1 to 4, the gap between male full-time and female part-time employees has been analysed in two stages; the difference between being full-time and part-time, and the gender difference. It is, of course, possible to consider this gap directly and the results for all of the models discussed above are presented in Table 5. These results are consistent with those presented in the models above and can be analysed in an analogous manner. For example, the earnings gap between full-time males and part-time females is the largest raw gap at 31.8 log per cent.

The summary in Table 5 shows that, for Model D, the majority of this gap is due to occupation differences (which from Figure 4 above we found to be primarily associated with being part-time) and industry difference (which we similarly found in Figure 4 to be associated with gender and being part-time). The effects of region and workplace characteristics on the overall earning gap are small, as would be expected given that they are not large in Figure 4 and that they are also of opposite signs moving across genders and across full-time to part-time status and so are partially offsetting. Finally, the unexplained component of the gap is sizeable at $13.5 \mathrm{log}$ percentage points, and we know from Figure 4 that this is primarily a gender related effect.

For each of the models discussed above a residual (or unexplained) part of the earnings gap remains. These are summarised in Table 6. As discussed above, they are measured as the difference between the parameters for each group evaluated at the mean level of the characteristics for the lower average earnings group. They therefore reflect differences in returns in terms of earnings for any given characteristic. A good example of such a difference is in the returns (coefficients or parameters from the earning equation estimations) to potential work experience. 
For model D the difference in average potential experience between full-time males and females (Table 1) contributes 2.4 log percentage points to the gap between their average earnings. Differences in the returns to experience (Table 4) contribute a further 1.5 log percentage points. The largest differences are between full and parttime employees. Male full-timers have higher potential experience than male parttime timers (Table 1) contributing 5.1 log percentage points to the gap in their earnings. The difference in the returns contributes 20.8 log percentage points. For females, the figures are $-1.4 \log$ percentage points and 14.2 log percentage points respectively. Thus, we can conclude that a significant part of the part-time penalty is due to part-timers receiving less as a return on their potential work experience. ${ }^{15}$

Similar arguments can be made in respect of the returns to education. Substantial differences in returns exist between female full and part-time employees with an impact of 7.6 log percentage points on the earnings gap, whilst the impact of the difference in educational qualifications is 4.0 log percentage points.

Compared with Manning and Petrongolo (2006), we find similar contributions of individual characteristics, industry and occupations. However, in addition we find that industry and workplace features explain nearly all of the remaining gap. This is also the feature missing from Hirsch (2005) in his analysis of the US full-time/parttime wage gap. He found a larger residual gap for females than our evidence for Britain suggests. This appears to be as a result of a smaller contribution from individual characteristics.

The male full-time part-time gap results in this report are rather different to the results for the UK presented by O’Dorchai et al (2007). The raw gap for males in the UK in 1995 that they identify from the European Structure of Earnings Survey is rather larger than the one we find from WERS04 (55 log per cent versus 11.7 log per cent). However, the extent of part time working by men the UK has expanded from 3 per cent in O’Dorchai et al to 12.2 per cent in WERS04. It is therefore no surprise that the nature of the earnings gap found in the results presented here differs somewhat from that reported by O’Dorchai et al.

\footnotetext{
${ }^{15}$ As discussed above, without work history data, we cannot allow for periods of time spent out the workforce which may be biasing the estimates of these returns downwards (Swaffield, 2007).
} 


\section{The importance of segregation}

Segregation of women into lower paying occupations and workplaces has been suggested as an important part of the explanation for the gender pay gap. In this section we examine how important this segregation is for pay gaps for the full and part-time employed.

In her early analysis, Groshen (1991), using US data, found that the majority of the earnings gap between men and women could be attributed to occupational segregation whilst little was due to segregation at the workplace. She concluded that there was a need for job evaluation systems based on comparable-worth principles ${ }^{16}$ in order to reduce the gap. Using a broader dataset, Bayard et al (2003) contradict Groshen's work finding that the majority of the earnings gap was due to the individual's gender and not explained by occupational segregation. They consequently advocated stronger enforcement of equal pay acts to reduce the gender pay gap. The present authors, using WERS98, found similar results to Bayard et al (2003) for Britain (Mumford and Smith, 2005). Substantial variations in these gaps were found across different sectors and regions in Britain. They concluded that workplace segregation had a significant and substantial impact, especially in Scotland and the North East where physical distances may limit the employment opportunities for women, suggesting a need to strengthen equal pay provisions to ensure acrossworkplace comparability and pay equity.

The impact of segregation is addressed here by adding the proportion of females in occupation or workplace to Model D to create Model E. This is therefore including a direct measure of femaleness to add to the wider influence of the workplace or occupation on the earnings gap which we present above.

As additional variables in Model E, these segregation effects have an important role. According to the estimates in Table 5, the proportion of females in the workplace has a negative impact on earnings for all employees, an effect which is significant for all but part-time males. By contrast, the concentration of females in the occupation is positively related to earnings for all but the part-time males. However, this is only significant for part-time females. It should be remembered that these effects are above and beyond the contribution of the occupation fixed effect and the

\footnotetext{
${ }^{16}$ Comparable worth pay policies seek to similarly remunerate different occupations that have similar job requirements - such as effort, skill, responsibility, working conditions, etc, but that otherwise appear to be very different. In this way male occupations can be compared to female.
} 
various individual and workplace variables which are also present in the model but whose parameter estimates are not reported in the table due to their similarity with the results in Table 4.

The impact on the decomposition of the earnings gaps between the various groups is shown in Figure 5. The proportion of females in the workplace has the biggest impact on the gender earnings gap; 2.5 of the 14 log per cent earnings gap between full-time employees and 2.9 of the 20.1 log per cent gap between part-time employees. ${ }^{17}$ For men, working in a feminised workplace is associated with higher relative pay (and vice-versa for women). It also provides more than 1 log percentage point to the gap between full and part-time employees, both males and females. In brief, female employees in more feminised workplaces have lower relative earnings and this has a greater effect on part-time women. The size of the effect across full and part time employees is somewhat smaller than that found in Mumford and Smith (2005) but remains much more important than the initial results of Groschen (1991) suggested.

The association between individual earnings and more feminised occupations is less clear cut. From Table 5 we see that the proportion of females in the occupation is only significant for part-time female earnings. It is not a surprise, therefore, to find from the decompositions in Figure 5 that the proportion of females in the occupation only contributes substantially to the gap in earnings between male and female parttimers. The 3.28 log per cent contribution to this earnings gap is large.

A complete summary of the effects of occupation on the earnings gaps can be constructed for comparison of males and females by adding the relevant contributions in Figure 5 together. For example, in total, occupation provides a $5.46(=2.18+3.28)$ log percentage point gap between male and female part-timer employees. This is very similar to the occupation impact found in Model D (Figure 4) of 5.65 log percentage points. What Model E tells us, therefore, is that for the earnings gap between part-time male and female employees, the contribution of occupation is as much due to the proportion of women working within those occupations as the occupation itself. This is a new result which develops that in Mumford and Smith (2005).

A final gap that can be examined is that between full time males and part time females. Table 5 shows that workplace segregation provides a 3.33 log per cent

\footnotetext{
${ }^{17}$ Similarly, workplace segregation provides 0.6 log per cent between male and female part-timers and 0.87 log per cent between full-timers.
} 
contribution to that earnings gap. Compared with the impact of the workplace variables as a whole, workplace segregation contributes substantially more to the explanation of that earnings gap.

The results here also show that both female occupational and, especially, workplace segregation remain significant and substantial contributors to the gender earnings gap. These results develop those for WERS98 and suggest that the effects of female segregation are persistent over time.

\section{Conclusions}

This study investigates the gender earnings gap for both part-time and full-time employees in Britain and the associated full-time/part-time earnings gap. We consider a four-way gender-working time split (male full-timers, male part-timers, female fulltimers and female part-timers). In addition to considering employee and workplace characteristics, we explicitly allow for the impact of segregation of females at both workplace and occupational level.

Within gender groups, the striking difference between full-time and part-time employees is that full-time employees work in higher paying occupations than do part-time employees; this has a substantial impact on differences in average earnings for both males and females. Individual and workplace characteristics also explain a substantial part of the full-time/part-time earnings gap.

Within full-time groups, the gender earnings gap is partly explained by individual and workplace characteristics. The industry in which the workplace is situated is an important determinant of higher relative earnings for full-time males. Amongst part timers, occupation and industry explain a substantial part of the gap. Individual characteristics, by contrast, would support higher relative earnings for part -time females.

Workplace segregation of women is shown to have an important effect on relative earnings. Female employees in more feminised workplaces have lower relative earnings and this has a greater effect on part-time women. Also, occupational segregation is shown to make a significant contribution to the earnings gap between male and female part time employees but not for full time workers. This, therefore, also makes a significant contribution to explaining the full-time male to part-time female earnings gap. 
Once possible determinants have been taken into account, substantial residual gender earnings gaps exist for full and part time employees. This remaining unexplained residual, due to differences in parameters, is often described as the pure gender or discrimination effect. The residual part time earnings gap, by contrast, is essentially zero for females. However, for males it is negative. This implies that, given all of these determinants of pay, we would expect the full-time part-time earnings gap for men to be twice as big as it is measured to be in practice.

The finding that a large pure gender earnings gap remains for both full and part-time employees suggests that the Equal Pay legislation in Britain has not been fully effective. An important policy response could therefore be more effective application of this legislation. The finding that segregation of females into occupations and workplaces accounts for a significant proportion of the raw earnings gap suggests that more vigorous application of comparable worth policies would also be necessary to further close the gender earnings gap. The new Equality Act (2006) with its Gender Equality Duty (GED) may prove to be more effective at lowering the gender pay gap in the future.

\section{References}

Abowd, J.M., F. Kramarz, D.N. Margolis, D.N., and Troske, K. 2001. 'The Relative Importance of Employer and Employee Effects on Compensation: A Comparison of France and the United States.' Journal of the Japanese and International Economies 15(4): 419-436.

Altonji, J.G. and Blank, R. 1999. 'Race and Gender in the Labor Market' in Ashenfelter, O. and Card, D. (eds.) Handbook of Labor Economics. Elsevier Science B.V, Amsterdam.

Anderson, T. Forth, J. Metcalf, H. and Kirby, S. 2004. 'The Gender Pay Gap.' Women and Equality Unit Report.

Bayard, K., Hellerstein, J., Neumark. D. and Troske, K. 2003 'New Evidence of Sex Segregation and Sex Differences in Wages from Matched Employee-Employer Data.' Journal of Labor Economics. 21: 887-922.

Bergmann, B.R. 1971. 'Occupational Segregation, Wages and Profits when Employers Discriminate by Race or Sex’. Eastern Economic Journal. 1:103-110.

Budd, J. W. and Mumford, K. 2003. 'Family Friendly Work Practices in Britain: Availability and Awareness. Mimeo, University of York. 
Connolly, S. and Gregory, M. 2007. 'Moving Down? Women's Part-Time Work and Occupational Change in Britain 1991-2001.' Department of Economics, University of Oxford Working Paper 302.

Deaton, A. 1998. The Analysis of Household Surveys. A Microeconometric Approach to Development Policy. World Bank. John Hopkins University Press, Baltimore.

Department for Communities and Local Government. April 2007. Towards a Fairer Future, Implementing the Women and Work Commission Recommendations. Department for Communities and Local Government Publications, UK.

Drolet, M. 2002. 'Can the Workplace Explain Canadian Gender Pay Differentials?' Mimeo Statistics Canada, presented at the New Zealand Conference on Database Integration and Linked Employer-Employee Data.

Fagan, C. and Hebson, G. 2004. 'Making Work Pay. Debates from a Gender Perspective: A Comparative Review of some Recent Policy Reforms in Thirty European Countries.' The Co-ordinators' Final Report for the EU Expert Group on Gender, Social Inclusion and Employment Expert Group (EGGSIE) to the Equal Opportunities Unit, Employment Directorate (DGV) European Commission.

Filer, R. 1986. 'The Role of Personality and Tastes in Determining Occupational Structure.' Industrial and Labor Relations Review 39, 412-424.

Freeman, R B., and Medoff., J.L. 1984. What Do Unions Do? New York: Basic Books.

Groshen, E. 1991. 'The Structure of the Female/Male Wage Differential. Is It Who You Are, What You Do, or Where You Work?' Journal of Human Resources 26(3): 457-472.

Harkness, S. 1996. 'The Gender Earnings Gap: Evidence from the UK.' Fiscal Studies 17: 1-36.

Hashimoto M. 1981 'Firm-specific Human Capital as a Shared Investment' American Economic Review, 71, 475-82.

Hirsch, B. 2005. 'Why do Part-Time Workers Earn Less? The Role of Worker and Job Skills’ Industrial and Labor Relations Review, 28, 4, 525-551.

Holzer, H. and Neumark, D. 2000. 'Assessing Affirmative Action.' Journal of Economic Literature 38: 83-568.

Joshi, H., and Paci, P. 1998. Unequal Pay for Men and Women. MIT Press, Cambridge Massachusetts.

Manning, A. and Robinson, H. 2004. 'Something in the Way She Moves: A Fresh Look at an Old Gap.' Oxford Economic Papers 56: 169-188.

Manning, A. and Petrongolo, B. 2004. 'The Part-Time Pay Penalty' Women and Equality Unit Report, Department of Trade and Industry. 
Manning, A. and Petrongolo, B. 2006. 'The Part-Time Pay Penalty for Women in Britain.’ IZA Discussion Paper no. 2419.

Millward, N., Woodland, S., Bryson, A., Forth, J. and Kirby, S. 2004. 'A Bibliography of Research Based on the Workplace Industrial Relations Survey Series.' Mimeo NIESR.

Mumford, K. and Smith, P.N. 2004. 'Job Tenure in Britain: Individual versus Workplace Effects.’ Economica 71; 275-298.

Mumford, K. and Smith, P.N. 2005. 'The Gender Earnings Gap in Britain: Including the Workplace.' IZA Discussion Paper no. 1109.

Oaxaca, R.L., and Ransom, M.R. 1994. 'On Discrimination and the Decomposition of Wage Differentials.’ Journal of Econometrics 61: 5-24.

O'Dorchai, S., Plasman, R. and Rycx, F. 2007. 'The Part-Time Wage Penalty in European Countries: How Large is it for Men?’ IZA Discussion Paper no. 2591.

Paull, G. 2006. 'The Impact of Children on Women's Paid Work.' Fiscal Studies 27 (4), 473-512

Reilly, K. Garcia, J. Hernandez, P. Lopez-Nicolas, A. and Zanchi, L. 2006. 'The Why of More or Less: Evidence from Spain on Gender Segregation at the Establishment Level of the Firm.' Mimeo Department of Economics, University of Leeds (March).

Stewart, M. 1983. 'On Least Square Estimation when the Dependent Variable is Grouped.’ Review of Economic Studies 50(4): 737-753.

Swaffield, J.K. 2007. 'Estimates of the Impact of Labour Market Attachment and Attitudes on the Female Wage.’ The Manchester School 75 (3), 349-371.

Tam, M. 1997. Part-Time Employment: A Bridge or a Trap? Ashgate Publishing Ltd, Avebury.

Weichselbaumer, D., and Winter-Ebmer, R. 2005. 'A Meta-Analysis of the International Gender Wage Gap.’ Journal of Economic Surveys 9(3): 479-511. 
Table 1. Descriptive statistics; full time males and females.

\begin{tabular}{|c|c|c|c|c|c|c|c|c|}
\hline & \multicolumn{2}{|c|}{ Male full-time } & \multicolumn{2}{|c|}{ Female full-time } & \multicolumn{2}{|c|}{ Male part-time } & \multicolumn{2}{|c|}{ Female part-time } \\
\hline & mean & s.e. & mean & s.e. & mean & s.e. & mean & s.e. \\
\hline log hourly pay & 2.249 & 0.012 & 2.109 & 0.011 & 2.131 & 0.036 & 1.930 & 0.014 \\
\hline potential experience & 23.959 & 0.212 & 21.269 & 0.246 & 22.208 & 0.666 & 24.899 & 0.309 \\
\hline training & 2.655 & 0.060 & 3.031 & 0.063 & 2.131 & 0.115 & 1.914 & 0.055 \\
\hline \multicolumn{9}{|l|}{ education measures: } \\
\hline educ none/other & 0.254 & 0.007 & 0.166 & 0.007 & 0.180 & 0.011 & 0.257 & 0.008 \\
\hline cse25 & 0.105 & 0.004 & 0.089 & 0.005 & 0.082 & 0.009 & 0.093 & 0.005 \\
\hline cse1 & 0.218 & 0.006 & 0.288 & 0.008 & 0.540 & 0.020 & 0.301 & 0.009 \\
\hline ceae & 0.045 & 0.003 & 0.057 & 0.004 & 0.147 & 0.013 & 0.067 & 0.004 \\
\hline ce2ae & 0.078 & 0.004 & 0.093 & 0.005 & 0.107 & 0.017 & 0.100 & 0.006 \\
\hline degree & 0.215 & 0.008 & 0.223 & 0.008 & 0.181 & 0.015 & 0.123 & 0.006 \\
\hline postgrad & 0.072 & 0.005 & 0.071 & 0.004 & 0.071 & 0.008 & 0.040 & 0.003 \\
\hline child 0-4 & 0.151 & 0.005 & 0.055 & 0.003 & 0.081 & 0.010 & 0.142 & 0.006 \\
\hline child 5-11 & 0.145 & 0.005 & 0.083 & 0.004 & 0.206 & 0.015 & 0.199 & 0.007 \\
\hline child 12-18 & 0.117 & 0.004 & 0.115 & 0.005 & 0.055 & 0.008 & 0.146 & 0.006 \\
\hline married & 0.697 & 0.006 & 0.614 & 0.008 & 0.139 & 0.014 & 0.715 & 0.009 \\
\hline disabled & 0.125 & 0.004 & 0.106 & 0.005 & 0.179 & 0.013 & 0.111 & 0.005 \\
\hline ethnic & 0.060 & 0.005 & 0.065 & 0.006 & 0.075 & 0.009 & 0.046 & 0.005 \\
\hline fixed contract & 0.026 & 0.003 & 0.032 & 0.003 & 0.055 & 0.007 & 0.030 & 0.003 \\
\hline part time & 0.000 & 0.000 & 0.000 & 0.000 & 1.000 & 0.000 & 1.000 & 0.000 \\
\hline tenure & 5.421 & 0.074 & 4.692 & 0.074 & 4.110 & 0.135 & 5.017 & 0.082 \\
\hline union & 0.327 & 0.012 & 0.325 & 0.011 & 0.264 & 0.017 & 0.290 & 0.011 \\
\hline female & 0.000 & 0.000 & 1.000 & 0.000 & 0.000 & 0.000 & 1.000 & 0.000 \\
\hline \multicolumn{9}{|l|}{ occupations: } \\
\hline managerial & 0.168 & 0.006 & 0.119 & 0.006 & 0.099 & 0.011 & 0.041 & 0.004 \\
\hline
\end{tabular}




\begin{tabular}{|c|c|c|c|c|c|c|c|c|}
\hline & \multicolumn{2}{|c|}{ Male full-time } & \multicolumn{2}{|c|}{ Female full-time } & \multicolumn{2}{|c|}{ Male part-time } & \multicolumn{2}{|c|}{ Female part-time } \\
\hline & mean & s.e. & mean & s.e. & mean & s.e. & mean & s.e. \\
\hline professional & 0.122 & 0.007 & 0.117 & 0.006 & 0.120 & 0.013 & 0.075 & 0.006 \\
\hline technical & 0.141 & 0.006 & 0.191 & 0.008 & 0.105 & 0.011 & 0.122 & 0.007 \\
\hline clerical & 0.085 & 0.005 & 0.297 & 0.010 & 0.074 & 0.009 & 0.235 & 0.011 \\
\hline craft & 0.146 & 0.009 & 0.013 & 0.002 & 0.084 & 0.012 & 0.012 & 0.003 \\
\hline personal & 0.023 & 0.003 & 0.084 & 0.007 & 0.065 & 0.008 & 0.149 & 0.008 \\
\hline sales & 0.039 & 0.004 & 0.090 & 0.008 & 0.145 & 0.017 & 0.183 & 0.012 \\
\hline operative & 0.152 & 0.009 & 0.037 & 0.006 & 0.078 & 0.011 & 0.017 & 0.003 \\
\hline unskilled & 0.124 & 0.008 & 0.052 & 0.005 & 0.230 & 0.018 & 0.165 & 0.010 \\
\hline \multicolumn{9}{|l|}{ industries } \\
\hline manufacturing & 0.275 & 0.012 & 0.115 & 0.008 & 0.110 & 0.012 & 0.039 & 0.004 \\
\hline utilities & 0.005 & 0.001 & 0.003 & 0.001 & 0.005 & 0.002 & 0.002 & 0.001 \\
\hline construction & 0.069 & 0.008 & 0.018 & 0.003 & 0.049 & 0.009 & 0.009 & 0.002 \\
\hline whole/retail & 0.125 & 0.010 & 0.120 & 0.009 & 0.218 & 0.020 & 0.208 & 0.013 \\
\hline hotels & 0.023 & 0.004 & 0.030 & 0.005 & 0.093 & 0.019 & 0.061 & 0.007 \\
\hline transport & 0.092 & 0.006 & 0.043 & 0.006 & 0.072 & 0.010 & 0.024 & 0.004 \\
\hline financial services & 0.056 & 0.005 & 0.080 & 0.007 & 0.034 & 0.006 & 0.058 & 0.007 \\
\hline other business & 0.156 & 0.011 & 0.168 & 0.012 & 0.092 & 0.013 & 0.096 & 0.011 \\
\hline public admin & 0.063 & 0.005 & 0.082 & 0.007 & 0.040 & 0.006 & 0.042 & 0.005 \\
\hline education & 0.041 & 0.003 & 0.101 & 0.006 & 0.097 & 0.010 & 0.164 & 0.009 \\
\hline health & 0.052 & 0.005 & 0.200 & 0.011 & 0.112 & 0.013 & 0.242 & 0.013 \\
\hline other community & 0.043 & 0.006 & 0.040 & 0.005 & 0.078 & 0.011 & 0.054 & 0.007 \\
\hline workplace age & 44.774 & 1.960 & 43.036 & 2.038 & 45.413 & 4.329 & 43.327 & 1.963 \\
\hline workplace size (/1000) & 0.477 & 0.039 & 0.563 & 0.063 & 0.356 & 0.057 & 0.444 & 0.057 \\
\hline multi site & 0.734 & 0.016 & 0.779 & 0.015 & 0.715 & 0.024 & 0.771 & 0.016 \\
\hline foreign owned & 0.188 & 0.015 & 0.118 & 0.011 & 0.101 & 0.014 & 0.074 & 0.010 \\
\hline increasing market & 0.333 & 0.017 & 0.328 & 0.016 & 0.424 & 0.025 & 0.331 & 0.018 \\
\hline age based wage & 0.442 & 0.018 & 0.535 & 0.018 & 0.409 & 0.023 & 0.427 & 0.019 \\
\hline grade based wage & 0.261 & 0.016 & 0.314 & 0.017 & 0.184 & 0.016 & 0.223 & 0.015 \\
\hline
\end{tabular}




\begin{tabular}{|c|c|c|c|c|c|c|c|c|}
\hline & \multicolumn{2}{|c|}{ Male full-time } & \multicolumn{2}{|c|}{ Female full-time } & \multicolumn{2}{|c|}{ Male part-time } & \multicolumn{2}{|c|}{ Female part-time } \\
\hline & mean & s.e. & mean & s.e. & mean & s.e. & mean & s.e. \\
\hline family friendly index & 2.927 & 0.055 & 3.288 & 0.048 & 2.817 & 0.077 & 3.050 & 0.055 \\
\hline equal opp & 0.842 & 0.013 & 0.890 & 0.010 & 0.804 & 0.024 & 0.860 & 0.013 \\
\hline rel female workplace & 0.319 & 0.776 & 0.647 & 0.624 & 0.462 & 1.264 & 0.756 & 0.655 \\
\hline rel female occupation & 0.410 & 0.482 & 0.605 & 0.444 & 0.497 & 0.829 & 0.639 & 0.418 \\
\hline interaction index & 2.553 & 0.043 & 2.721 & 0.039 & 2.405 & 0.058 & 2.493 & 0.047 \\
\hline IR index & 1.212 & 0.032 & 1.243 & 0.031 & 1.143 & 0.041 & 1.216 & 0.033 \\
\hline \multicolumn{9}{|l|}{ regions: } \\
\hline north east & 0.041 & 0.008 & 0.032 & 0.005 & 0.037 & 0.008 & 0.040 & 0.007 \\
\hline north west & 0.146 & 0.013 & 0.145 & 0.013 & 0.168 & 0.020 & 0.141 & 0.014 \\
\hline yorkshire \& the humber & 0.094 & 0.012 & 0.090 & 0.011 & 0.110 & 0.016 & 0.102 & 0.012 \\
\hline east midlands & 0.074 & 0.009 & 0.065 & 0.009 & 0.056 & 0.010 & 0.068 & 0.010 \\
\hline west midlands & 0.100 & 0.012 & 0.088 & 0.010 & 0.096 & 0.015 & 0.107 & 0.013 \\
\hline east of england & 0.089 & 0.011 & 0.090 & 0.010 & 0.096 & 0.015 & 0.095 & 0.011 \\
\hline london & 0.102 & 0.010 & 0.125 & 0.012 & 0.085 & 0.013 & 0.077 & 0.009 \\
\hline south east & 0.124 & 0.012 & 0.140 & 0.013 & 0.114 & 0.015 & 0.129 & 0.013 \\
\hline south west & 0.079 & 0.009 & 0.084 & 0.010 & 0.082 & 0.013 & 0.087 & 0.012 \\
\hline scotland & 0.114 & 0.013 & 0.106 & 0.011 & 0.115 & 0.018 & 0.113 & 0.012 \\
\hline wales & 0.036 & 0.006 & 0.036 & 0.006 & 0.042 & 0.010 & 0.042 & 0.008 \\
\hline No. observations & & 8661 & & 6424 & & 1180 & & 4863 \\
\hline
\end{tabular}

Source: WERS 2004. 
Table 2. Model A, weighted OLS; full and part time, male and female.

\begin{tabular}{|c|c|c|c|c|c|c|c|c|}
\hline \multirow[t]{2}{*}{ log hourly pay } & \multicolumn{2}{|c|}{ Male full-time } & \multicolumn{2}{|c|}{ Female full-time } & \multicolumn{2}{|c|}{ Male part-time } & \multicolumn{2}{|c|}{ Female part-time } \\
\hline & coeff & t-value & coeff & $\mathrm{t}$-value & coeff & $\mathrm{t}$-value & coeff & t-value \\
\hline potential experience & 0.031 & $15.30^{*}$ & 0.036 & 0.00 & 0.035 & $4.38^{*}$ & 0.038 & $9.76^{*}$ \\
\hline pot exp sqd (x1000) & -0.454 & $-11.42^{*}$ & -0.629 & $-12.86^{*}$ & -0.641 & $-4.19^{\star}$ & -0.702 & $-8.84^{*}$ \\
\hline training & 0.012 & $6.22^{*}$ & 0.016 & $8.78^{\star}$ & 0.039 & $4.29^{*}$ & 0.023 & $5.41^{*}$ \\
\hline \multicolumn{9}{|c|}{ education none/other is omitted } \\
\hline cse25 & 0.140 & $8.09^{*}$ & 0.108 & $4.28^{*}$ & 0.180 & 1.54 & 0.048 & 1.49 \\
\hline cse1 & 0.257 & $15.71^{*}$ & 0.234 & $11.74^{*}$ & 0.291 & $2.9^{*}$ & 0.165 & $6.54^{*}$ \\
\hline ceae & 0.283 & $10.17^{\star}$ & 0.320 & $9.63^{*}$ & 0.289 & 1.94 & 0.205 & $4.93^{*}$ \\
\hline ce2ae & 0.458 & $18.11^{*}$ & 0.372 & $14.07^{\star}$ & 0.273 & 2.48 & 0.369 & $6.88^{\star}$ \\
\hline degree & 0.607 & $30.42^{\star}$ & 0.587 & $24.23^{*}$ & 0.465 & $4.65^{*}$ & 0.581 & $13.56^{*}$ \\
\hline postgrad & 0.787 & $32.51^{*}$ & 0.725 & $26.00^{*}$ & 0.530 & $4.77^{*}$ & 0.703 & $13.91^{*}$ \\
\hline child $0-4$ & 0.055 & $3.64^{\star}$ & 0.040 & 1.67 & -0.085 & -0.87 & -0.004 & -0.11 \\
\hline child 5-11 & 0.036 & $2.24^{*}$ & -0.037 & -1.74 & 0.122 & 1.25 & -0.143 & $-4.06^{*}$ \\
\hline child $12-18$ & 0.022 & 1.35 & -0.114 & $-5.78^{\star}$ & 0.188 & 1.57 & -0.142 & $-4.45^{*}$ \\
\hline married & 0.104 & $8.23^{*}$ & 0.012 & 0.97 & 0.177 & $2.26^{*}$ & 0.059 & $2.34^{*}$ \\
\hline disabled & -0.027 & -1.80 & -0.052 & $-2.92^{*}$ & -0.147 & $-2.06^{\star}$ & 0.014 & 0.40 \\
\hline ethnic & -0.105 & $-3.53^{\star}$ & -0.061 & -1.89 & -0.201 & $-2.42^{\star}$ & -0.019 & -0.35 \\
\hline fixed contract & -0.030 & -0.63 & -0.017 & -0.55 & 0.113 & 1.29 & 0.081 & 1.58 \\
\hline tenure & 0.017 & $9.01^{*}$ & 0.011 & $5.43^{*}$ & 0.031 & $3.07^{*}$ & 0.014 & $4.74^{*}$ \\
\hline union & -0.024 & -1.54 & 0.039 & $2.62^{*}$ & 0.225 & $3.34^{*}$ & 0.163 & $6.88^{*}$ \\
\hline constant & 1.324 & $48.58 *$ & 1.306 & $47.82^{*}$ & 1.222 & $11.64^{*}$ & 1.178 & $27.02^{\star}$ \\
\hline strata & & 89 & & 89 & & 84 & & 86 \\
\hline PSUs & & 1424 & & 1445 & & 750 & & 1254 \\
\hline No. observations & & 8661 & & 6424 & & 1180 & & 4863 \\
\hline Degrees freedom & & 1335 & & 1356 & & 666 & & 1168 \\
\hline R-squared & & 0.38 & & 0.347 & & 0.235 & & 0.231 \\
\hline
\end{tabular}

Source: WERS $2004{ }^{*}$ significant at a 95\% confidence level or above. 
Table 3. Model B, weighted OLS; full and part time, male and female.

\begin{tabular}{|c|c|c|c|c|c|c|c|c|}
\hline \multirow[t]{2}{*}{ log hourly pay } & \multicolumn{2}{|c|}{ Male full-time } & \multicolumn{2}{|c|}{ Female full-time } & \multicolumn{2}{|c|}{ Male part-time } & \multicolumn{2}{|c|}{ Female part-time } \\
\hline & coeff & t-value & coeff & $\mathrm{t}$-value & coeff & $\mathrm{t}$-value & coeff & $\mathrm{t}$-value \\
\hline potential experience & 0.027 & $15.03^{*}$ & 0.031 & $14.29 *$ & 0.017 & $2.14^{*}$ & 0.024 & $6.84^{\star}$ \\
\hline pot exp sqd (x1000) & -0.399 & $-11.42^{*}$ & -0.546 & $-11.89^{*}$ & -0.342 & $-2.27^{\star}$ & -0.497 & $-6.79 *$ \\
\hline training & 0.004 & $2.75^{\star}$ & 0.008 & $4.74^{*}$ & 0.022 & $2.74^{*}$ & 0.010 & $2.68^{\star}$ \\
\hline \multicolumn{9}{|c|}{ education none/other is omitted } \\
\hline cse25 & 0.082 & $5.37^{*}$ & 0.074 & $3.09^{*}$ & 0.152 & 1.33 & -0.022 & -0.71 \\
\hline cse1 & 0.138 & $9.28^{*}$ & 0.142 & $7.86^{*}$ & 0.177 & 1.82 & 0.017 & 0.68 \\
\hline ceae & 0.140 & $5.57^{*}$ & 0.188 & $6.34^{*}$ & 0.115 & 0.75 & 0.017 & 0.42 \\
\hline ce2ae & 0.277 & $12.82^{*}$ & 0.219 & $9.22^{*}$ & 0.212 & 1.94 & 0.166 & $3.57^{*}$ \\
\hline degree & 0.354 & $18.33^{*}$ & 0.368 & $16.46^{*}$ & 0.239 & $2.08^{\star}$ & 0.219 & $5.37^{\star}$ \\
\hline postarad & 0.484 & $18.28^{*}$ & 0.459 & $16.59 *$ & 0.263 & $2.13^{\star}$ & 0.236 & $4.79 *$ \\
\hline child 0-4 & 0.053 & $3.98^{*}$ & 0.033 & 1.48 & -0.057 & -0.57 & -0.037 & -1.27 \\
\hline child 5-11 & 0.036 & $2.48^{*}$ & -0.038 & -1.87 & 0.118 & 1.27 & -0.109 & $-3.56^{\star}$ \\
\hline child 12-18 & 0.024 & 1.56 & -0.093 & $-5.44^{*}$ & 0.179 & 1.75 & -0.103 & $-3.57^{\star}$ \\
\hline married & 0.069 & $6.02^{*}$ & 0.004 & 0.38 & 0.043 & 0.62 & 0.033 & 1.52 \\
\hline disabled & -0.029 & $-2.30^{\star}$ & -0.033 & -1.94 & -0.167 & $-2.62^{\star}$ & -0.011 & -0.35 \\
\hline ethnic & -0.047 & $-2.07^{\star}$ & -0.023 & -0.92 & -0.105 & -1.35 & -0.021 & -0.45 \\
\hline fixed contract & -0.052 & -1.36 & -0.050 & -1.78 & 0.021 & 0.27 & 0.041 & 0.96 \\
\hline tenure & 0.013 & $7.66^{*}$ & 0.010 & $5.65^{*}$ & 0.023 & $2.37^{*}$ & 0.009 & $3.42^{*}$ \\
\hline union & 0.030 & $2.18^{*}$ & 0.022 & 1.66 & 0.241 & $3.95^{*}$ & 0.120 & $5.71^{*}$ \\
\hline \multicolumn{9}{|l|}{ clerical is omitted } \\
\hline managerial & 0.255 & $11.66^{*}$ & 0.220 & $9.43^{*}$ & 0.509 & $4.08^{*}$ & 0.434 & $5.34^{*}$ \\
\hline professional & 0.220 & $8.66^{*}$ & 0.273 & $12.61^{*}$ & 0.346 & $2.97^{*}$ & 0.444 & $9.98^{*}$ \\
\hline technical & 0.148 & $6.15^{*}$ & 0.161 & $10.67^{\star}$ & 0.199 & 1.72 & 0.245 & $7.48^{*}$ \\
\hline craft & -0.047 & $-2.07^{\star}$ & -0.132 & $-2.83^{*}$ & 0.176 & 0.94 & -0.321 & $-2.93^{\star}$ \\
\hline personal & -0.211 & $-6.29^{*}$ & -0.238 & $-10.05^{\star}$ & -0.283 & $-2.58^{*}$ & -0.254 & $-9.27^{*}$ \\
\hline sales & -0.222 & $-6.63^{*}$ & -0.179 & $-7.19^{*}$ & -0.495 & $-4.75^{\star}$ & -0.304 & $-9.69 *$ \\
\hline operative & -0.192 & $-7.68^{\star}$ & -0.246 & $-6.81^{*}$ & -0.101 & -0.87 & -0.126 & -1.21 \\
\hline unskilled & -0.324 & $-12.13^{*}$ & -0.303 & $-11.68^{*}$ & -0.411 & $-4.00^{*}$ & -0.399 & $-13.71^{*}$ \\
\hline constant & 1.569 & $50.94^{*}$ & 1.503 & $55.98^{*}$ & 1.703 & $11.81^{*}$ & 1.660 & $34.18^{*}$ \\
\hline strata & & 89 & & 89 & & 84 & & 86 \\
\hline PSUs & & 1424 & & 1445 & & 750 & & 1254 \\
\hline No. observations & & 8661 & & 6424 & & 1180 & & 4863 \\
\hline Degrees freedom & & 1335 & & 1356 & & 666 & & 1168 \\
\hline R-squared & & 0.513 & & 0.475 & & 0.35 & & \\
\hline
\end{tabular}

Source: WERS 2004. * significant at a 95\% confidence level or above. 
Table 4. Model D, weighted OLS; full and part time, male and female.

\begin{tabular}{|c|c|c|c|c|c|c|c|c|}
\hline \multirow[t]{2}{*}{ log hourly pay } & \multicolumn{2}{|c|}{ Male full-time } & \multicolumn{2}{|c|}{ Female full-time } & \multicolumn{2}{|c|}{ Male part-time } & \multicolumn{2}{|c|}{ Female part-time } \\
\hline & coeff & t-value & coeff & t-value & coeff & t-value & coeff & t-value \\
\hline potential experience & 0.025 & $15.32^{\star}$ & 0.028 & 14.55 & 0.011 & 1.55 & 0.020 & $5.88^{\star}$ \\
\hline pot exp sqd (x1000) & -0.370 & $-11.46^{*}$ & -0.478 & $-11.87^{*}$ & -0.241 & -1.70 & -0.411 & $-5.88^{*}$ \\
\hline training & 0.004 & $2.59 *$ & 0.006 & $4.32^{\star}$ & 0.019 & $2.87^{\star}$ & 0.011 & $3.03^{\star}$ \\
\hline \multicolumn{9}{|c|}{ education none/other is omitted } \\
\hline cse25 & 0.083 & $5.64^{\star}$ & 0.070 & $3.32^{\star}$ & 0.175 & 1.82 & -0.017 & -0.56 \\
\hline $\operatorname{cse} 1$ & 0.126 & $9.20^{*}$ & 0.127 & $7.99^{\star}$ & 0.129 & 1.57 & 0.017 & 0.71 \\
\hline ceae & 0.133 & $5.89^{\star}$ & 0.163 & $6.02^{\star}$ & 0.183 & 1.47 & 0.022 & 0.61 \\
\hline ce2ae & 0.238 & $12.58^{*}$ & 0.192 & $8.96^{\star}$ & 0.256 & $2.87^{\star}$ & 0.154 & $3.52^{\star}$ \\
\hline degree & 0.314 & $19.25^{*}$ & 0.329 & $16.16^{*}$ & 0.272 & $3.09^{*}$ & 0.207 & $5.44^{\star}$ \\
\hline postgrad & 0.440 & $19.72^{*}$ & 0.391 & $16.07^{*}$ & 0.345 & $3.35^{\star}$ & 0.209 & $4.60^{\star}$ \\
\hline child 0-4 & 0.057 & $4.90^{\star}$ & 0.038 & $1.96^{\star}$ & -0.082 & -0.97 & -0.075 & $-2.65^{\star}$ \\
\hline child 5-11 & 0.046 & $3.48^{\star}$ & -0.014 & -0.75 & 0.033 & 0.38 & -0.112 & $-3.80^{\star}$ \\
\hline child 12-18 & 0.030 & $2.18^{\star}$ & -0.060 & $-3.77^{\star}$ & 0.154 & 1.62 & -0.085 & $-3.28 *$ \\
\hline married & 0.068 & $6.58^{\star}$ & 0.021 & $2.18^{\star}$ & 0.030 & 0.49 & 0.029 & 1.41 \\
\hline disabled & -0.022 & -1.83 & -0.042 & $-2.71^{*}$ & -0.173 & $-3.18^{*}$ & -0.012 & -0.45 \\
\hline ethnic & -0.073 & $-3.66^{\star}$ & -0.111 & $-4.96^{\star}$ & -0.104 & -1.43 & -0.100 & $-2.37^{\star}$ \\
\hline fixed contract & -0.025 & -0.73 & -0.059 & $-1.98^{*}$ & 0.058 & 0.71 & 0.030 & 0.73 \\
\hline tenure & 0.012 & $8.30^{\star}$ & 0.010 & $6.50^{*}$ & 0.017 & $2.08^{*}$ & 0.008 & $3.01^{*}$ \\
\hline union & 0.018 & 1.36 & 0.021 & 1.81 & 0.149 & $2.78^{\star}$ & 0.095 & $4.54^{\star}$ \\
\hline \multicolumn{9}{|l|}{ clerical is omitted } \\
\hline managerial & 0.261 & $13.17^{\star}$ & 0.247 & $11.99^{\star}$ & 0.614 & $5.59^{\star}$ & 0.441 & $5.83^{\star}$ \\
\hline professional & 0.223 & $9.24^{*}$ & 0.310 & $14.03^{*}$ & 0.455 & $4.10^{*}$ & 0.527 & $11.47^{\star}$ \\
\hline technical & 0.141 & $6.59^{\star}$ & 0.165 & $12.08^{\star}$ & 0.277 & $2.47^{\star}$ & 0.271 & $8.44^{*}$ \\
\hline crafts & -0.016 & -0.77 & -0.064 & -1.56 & 0.170 & 1.13 & -0.250 & $-2.78^{*}$ \\
\hline personal & -0.115 & $-3.74^{*}$ & -0.179 & $-8.36^{*}$ & -0.067 & -0.62 & -0.173 & $-6.35^{\star}$ \\
\hline sales & -0.168 & $-5.56^{*}$ & -0.091 & $-3.80^{*}$ & -0.291 & $-2.71^{\star}$ & -0.171 & $-4.69 *$ \\
\hline operative & -0.155 & $-6.67^{*}$ & -0.175 & $-5.69^{*}$ & -0.129 & -1.09 & -0.157 & -1.41 \\
\hline unskilled & -0.270 & $-10.62^{*}$ & -0.217 & $-9.09 *$ & -0.241 & $-2.45^{\star}$ & -0.301 & $-10.57^{\star}$ \\
\hline \multicolumn{9}{|c|}{ manufacturing is omitted } \\
\hline utilities & 0.117 & $2.24^{*}$ & 0.139 & $2.93^{\star}$ & 0.324 & 1.06 & -0.080 & -0.88 \\
\hline construction & 0.053 & $2.00^{*}$ & 0.006 & 0.09 & -0.002 & -0.01 & 0.208 & 1.36 \\
\hline whole/retail & -0.094 & $-3.48^{*}$ & -0.115 & $-3.65^{\star}$ & -0.631 & $-4.65^{\star}$ & -0.333 & $-4.68^{*}$ \\
\hline hotels & -0.288 & $-6.97^{\star}$ & -0.204 & $-6.75^{\star}$ & -0.865 & $-5.28 *$ & -0.346 & $-5.04^{*}$ \\
\hline transport & 0.015 & 0.55 & 0.068 & $2.08^{\star}$ & -0.150 & -1.13 & -0.019 & -0.22 \\
\hline financial services & 0.047 & 1.64 & 0.064 & $2.47^{\star}$ & -0.437 & $-2.57^{*}$ & -0.057 & -0.70 \\
\hline other business & 0.017 & 0.69 & 0.058 & $2.30^{*}$ & -0.432 & $-3.31^{*}$ & -0.096 & -1.27 \\
\hline public admin & -0.069 & $-2.44^{*}$ & 0.012 & 0.49 & -0.205 & -1.08 & -0.117 & -1.64 \\
\hline education & -0.207 & $-6.93^{*}$ & -0.104 & $-3.82^{*}$ & -0.681 & $-4.91^{*}$ & -0.294 & $-4.23^{*}$ \\
\hline health & -0.136 & $-5.61^{*}$ & -0.049 & $-2.02^{*}$ & -0.621 & $-4.82^{*}$ & -0.246 & $-3.66^{*}$ \\
\hline other community & -0.095 & $-3.11^{*}$ & -0.025 & -0.71 & -0.552 & $-3.81^{*}$ & -0.307 & $-3.90 *$ \\
\hline workplace age & 0.000 & 0.20 & 0.000 & 1.22 & 0.000 & 0.73 & 0.000 & 1.02 \\
\hline workplace size & 0.013 & $2.11^{*}$ & 0.013 & $3.37^{\star}$ & -0.006 & -0.25 & 0.012 & 1.54 \\
\hline multi site & 0.003 & 0.16 & 0.007 & 0.44 & 0.070 & 1.12 & -0.031 & -1.11 \\
\hline foreign owned & 0.046 & $2.64^{*}$ & 0.054 & $2.59^{*}$ & -0.068 & -0.77 & 0.001 & 0.03 \\
\hline increasing market & -0.035 & $-2.54^{*}$ & -0.025 & -1.79 & -0.077 & -1.50 & 0.024 & 1.01 \\
\hline age based wage & 0.027 & 1.94 & 0.015 & 1.13 & 0.032 & 0.59 & 0.007 & 0.34 \\
\hline grade based wage & 0.032 & $1.97^{\star}$ & 0.023 & 1.66 & 0.141 & $2.18^{\star}$ & 0.017 & 0.72 \\
\hline family friendly index & 0.026 & $4.94^{*}$ & 0.030 & $6.58^{\star}$ & 0.002 & 0.09 & 0.016 & $2.14^{*}$ \\
\hline interaction index & 0.017 & $2.82^{\star}$ & 0.017 & $2.86^{\star}$ & 0.032 & 1.32 & 0.018 & 1.85 \\
\hline IR index & -0.001 & -0.15 & -0.015 & -1.91 & -0.022 & -0.70 & -0.003 & -0.20 \\
\hline equal opp & 0.017 & 0.82 & -0.001 & -0.03 & 0.058 & 0.64 & 0.012 & 0.36 \\
\hline
\end{tabular}




\begin{tabular}{|c|c|c|c|c|c|c|c|c|}
\hline & \multicolumn{2}{|c|}{ Male full-time } & \multicolumn{2}{|c|}{ Female full-time } & \multicolumn{2}{|c|}{ Male part-time } & \multicolumn{2}{|c|}{ Female part-time } \\
\hline & coeff & t-value & coeff & t-value & coeff & t-value & coeff & t-value \\
\hline \multicolumn{9}{|c|}{ east midlands is omitted } \\
\hline north east & -0.004 & -0.09 & -0.096 & $-2.30^{\star}$ & 0.053 & 0.43 & 0.071 & 1.23 \\
\hline $\begin{array}{l}\text { north west } \\
\text { yorkshire \& the }\end{array}$ & -0.029 & -0.97 & -0.053 & -1.58 & -0.044 & -0.51 & 0.017 & 0.41 \\
\hline humber & 0.014 & 0.48 & -0.019 & -0.55 & -0.107 & -1.14 & 0.035 & 0.79 \\
\hline west midlands & 0.029 & 0.95 & -0.044 & -1.31 & -0.014 & -0.14 & 0.009 & 0.23 \\
\hline east of england & 0.083 & $2.52^{\star}$ & 0.025 & 0.73 & 0.136 & 1.15 & 0.092 & 1.95 \\
\hline london & 0.213 & $6.78^{*}$ & 0.227 & $6.77^{\star}$ & 0.160 & 1.69 & 0.324 & $6.80^{*}$ \\
\hline south east & 0.120 & $4.33^{\star}$ & 0.089 & $2.68^{*}$ & 0.101 & 0.94 & 0.100 & $2.49 *$ \\
\hline south west & 0.015 & 0.46 & 0.001 & 0.04 & -0.103 & -0.98 & 0.021 & 0.44 \\
\hline scotland & -0.001 & -0.02 & 0.005 & 0.14 & -0.043 & -0.44 & 0.105 & $2.59 *$ \\
\hline wales & -0.004 & -0.11 & -0.087 & $-2.22^{\star}$ & -0.166 & -1.54 & 0.091 & 1.80 \\
\hline constant & 1.421 & $28.30 *$ & 1.364 & $28.51^{*}$ & 2.011 & $9.65^{\star}$ & 1.726 & $19.77^{*}$ \\
\hline strata & & 89 & & 89 & & 84 & & 86 \\
\hline PSUs & & 1424 & & 1445 & & 750 & & 1254 \\
\hline No. observations & & 8661 & & 6424 & & 1180 & & 4863 \\
\hline Degrees freedom & & 1335 & & 1356 & & 666 & & 1168 \\
\hline R-squared & & 0.586 & & 0.567 & & 0.451 & & 0.428 \\
\hline
\end{tabular}

Source: WERS 2004. *significant at a 95\% confidence level or above. 
Table 5. Decomposition of the Earnings Gap for Male Full Time versus Female Part Time

\begin{tabular}{|c|c|c|c|c|c|c|c|c|}
\hline Total Gap & 31.82 & & & & & & & \\
\hline Model & $\begin{array}{l}\text { Individual } \\
\text { Characteristics }\end{array}$ & Occupation & Industry & Workplace & Region & $\begin{array}{l}\text { Relative } \\
\text { Female } \\
\text { Workplace }\end{array}$ & $\begin{array}{l}\text { Relative } \\
\text { Female } \\
\text { Occupation }\end{array}$ & Unexplained \\
\hline Model A (OLS) & 5.19 & & & & & & & 26.64 \\
\hline Model B (OLS) & 3.24 & 8.49 & & & & & & 20.09 \\
\hline Model C (FE) & 1.92 & 5.49 & & & & & & 24.40 \\
\hline Model D (OLS) & 2.67 & 7.26 & 7.52 & 0.46 & 0.39 & & & 13.51 \\
\hline Model E (OLS) & 2.67 & 7.86 & 6.58 & 0.42 & 0.39 & 3.33 & -0.88 & 11.46 \\
\hline
\end{tabular}

Source: WERS 2004. All figures are expressed in log percentage points.

Table 6. Total and Residual Gaps

$\begin{array}{ccccc}\begin{array}{c}\text { Male full-time vs female } \\ \text { full-time }\end{array} & \begin{array}{c}\text { Male full-time vs male } \\ \text { full-time }\end{array} & \begin{array}{c}\text { Female full-time vs } \\ \text { female part-time }\end{array} & \begin{array}{c}\text { Male part-time vs } \\ \text { female part-time }\end{array} & \begin{array}{c}\text { Male full-time vs female } \\ \text { part-time }\end{array}\end{array}$

Total Gap

14.0

11.7

17.9

20.1

31.8

Residual Gap

Model A (OLS)

Model B (OLS)

Model C (FE)

Model D (OLS)

11.5

13.3

12.8

11.0

$-11.2$

$\begin{array}{ll}0.2 & 10.7\end{array}$

$\begin{array}{ll}-4.9 & 3.5 \\ -0.8 & 8.1\end{array}$

3.5
8.1

8.1
0.2

Model E (OLS)

$\begin{array}{ll}-11.7 & -0.7\end{array}$

0.7
$-0.7-12.4$

$34.2 \quad 26.6$

$22.3-20.1$

$18.5 \quad 24.4$

$12.4-13.5$

Source: WERS 2004. All figures are expressed in log percentage points. 
Table 7. Model E, weighted OLS; full and part time, male and female: selected results.

\begin{tabular}{|c|c|c|c|c|c|c|c|c|}
\hline \multirow[t]{2}{*}{ log hourly pay } & \multicolumn{2}{|c|}{ Male full-time } & \multicolumn{2}{|c|}{ Female full-time } & \multicolumn{2}{|c|}{ Male part-time } & \multicolumn{2}{|c|}{ Female part-time } \\
\hline & coeff & $\mathrm{t}$-value & coeff & t-value & coeff & t-value & coeff & t-value \\
\hline rel female workplace & -0.076 & $-2.31^{*}$ & -0.142 & $-5.01^{\star}$ & -0.0997 & -0.99 & -0.208 & $-4.12^{*}$ \\
\hline rel female occupation & 0.039 & 1.25 & 0.091 & 1.60 & -0.230 & -1.06 & 0.350 & $2.70^{*}$ \\
\hline \multicolumn{9}{|l|}{ All variables from } \\
\hline Model D also included & yes & & yes & & yes & & yes & \\
\hline strata & & 89 & & 89 & & 84 & & 86 \\
\hline PSUs & & 1424 & & 1445 & & 750 & & 1254 \\
\hline No. observations & & 8661 & & 6424 & & 1180 & & 4863 \\
\hline Degrees freedom & & 1335 & & 1356 & & 666 & & 1168 \\
\hline R-squared & & 0.587 & & 0.571 & & 0.451 & & 0.431 \\
\hline
\end{tabular}

Source: WERS 2004. *significant at a 95\% confidence level or above.

Figure 1. Decompositions of the Earnings Gaps : Model A : OLS

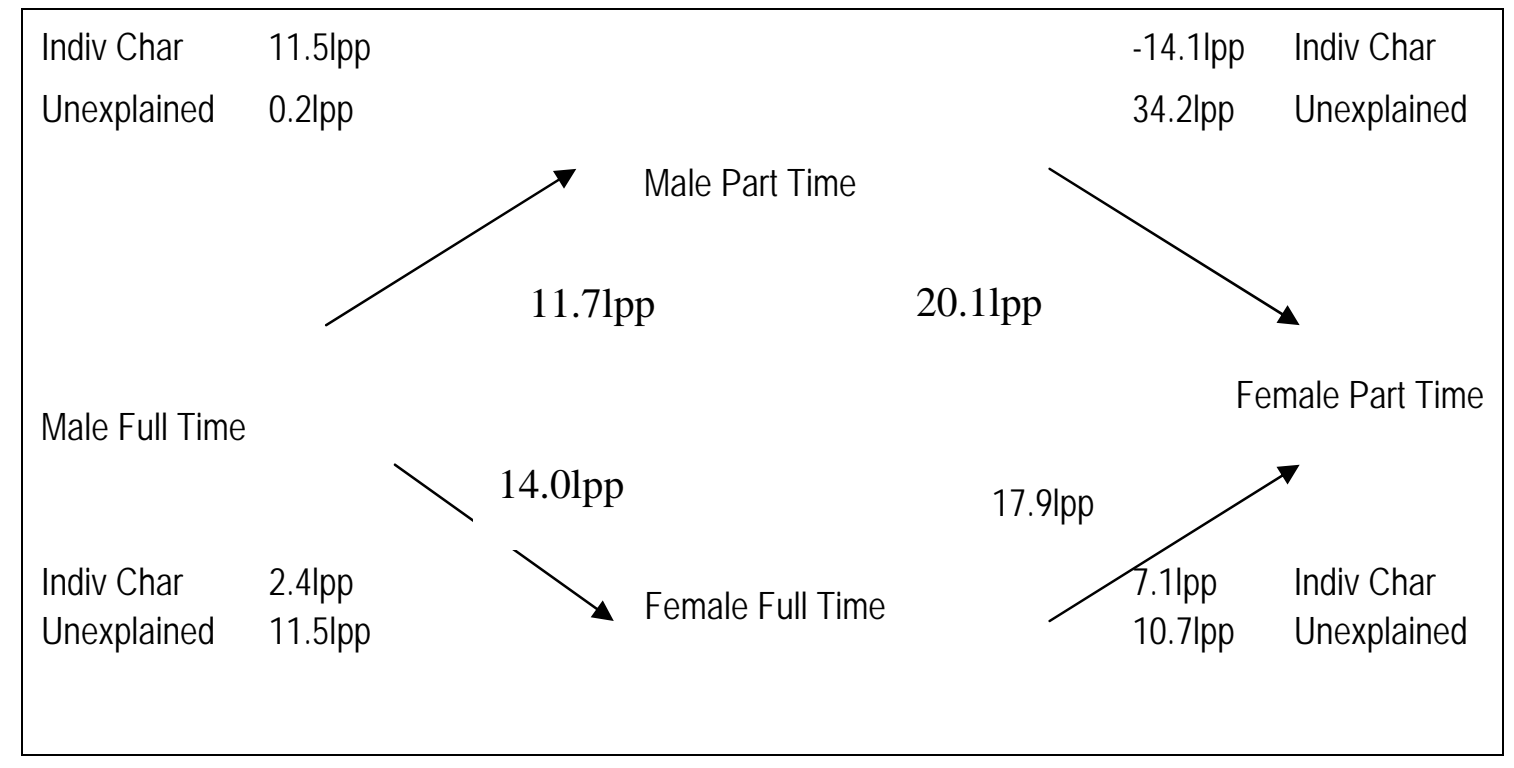

Notes: Each total bilateral earnings gap is presented next to an arrow indicating the direction of the comparison. In each case the contribution of each group of variables is evaluated using the parameters from the model for the higher earnings group. All figures are expressed in log-percentage points. 
Figure 2. Decompositions of the Earnings Gaps : Model B : OLS

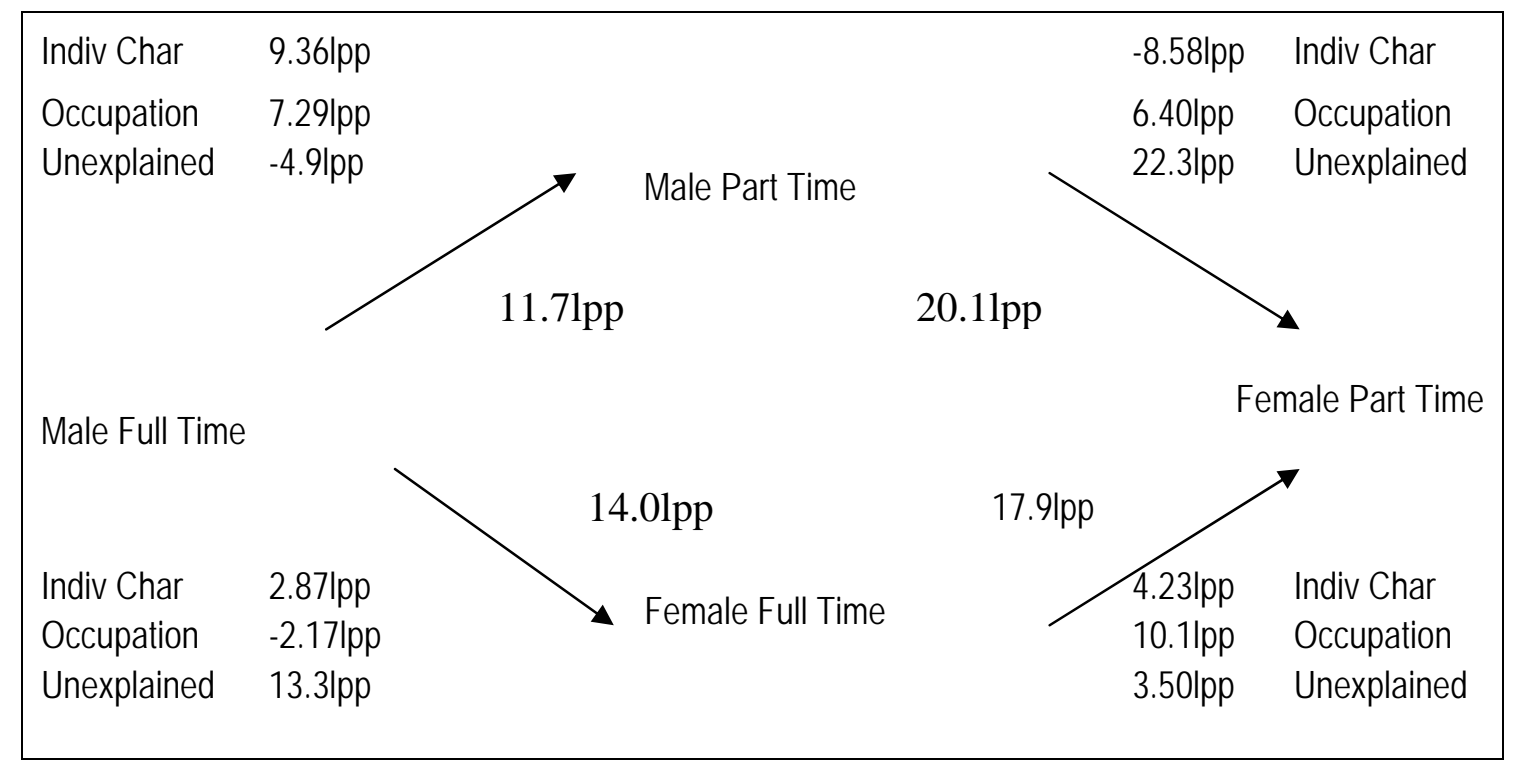

Notes: Each total bilateral earnings gap is presented next to an arrow indicating the direction of the comparison. In each case the contribution of each group of variables is evaluated using the parameters from the model for the higher earnings group. All figures are expressed in log-percentage points.

\section{Figure 3. Decompositions of the Earnings Gaps : Model C : Fixed Workplace Effects}

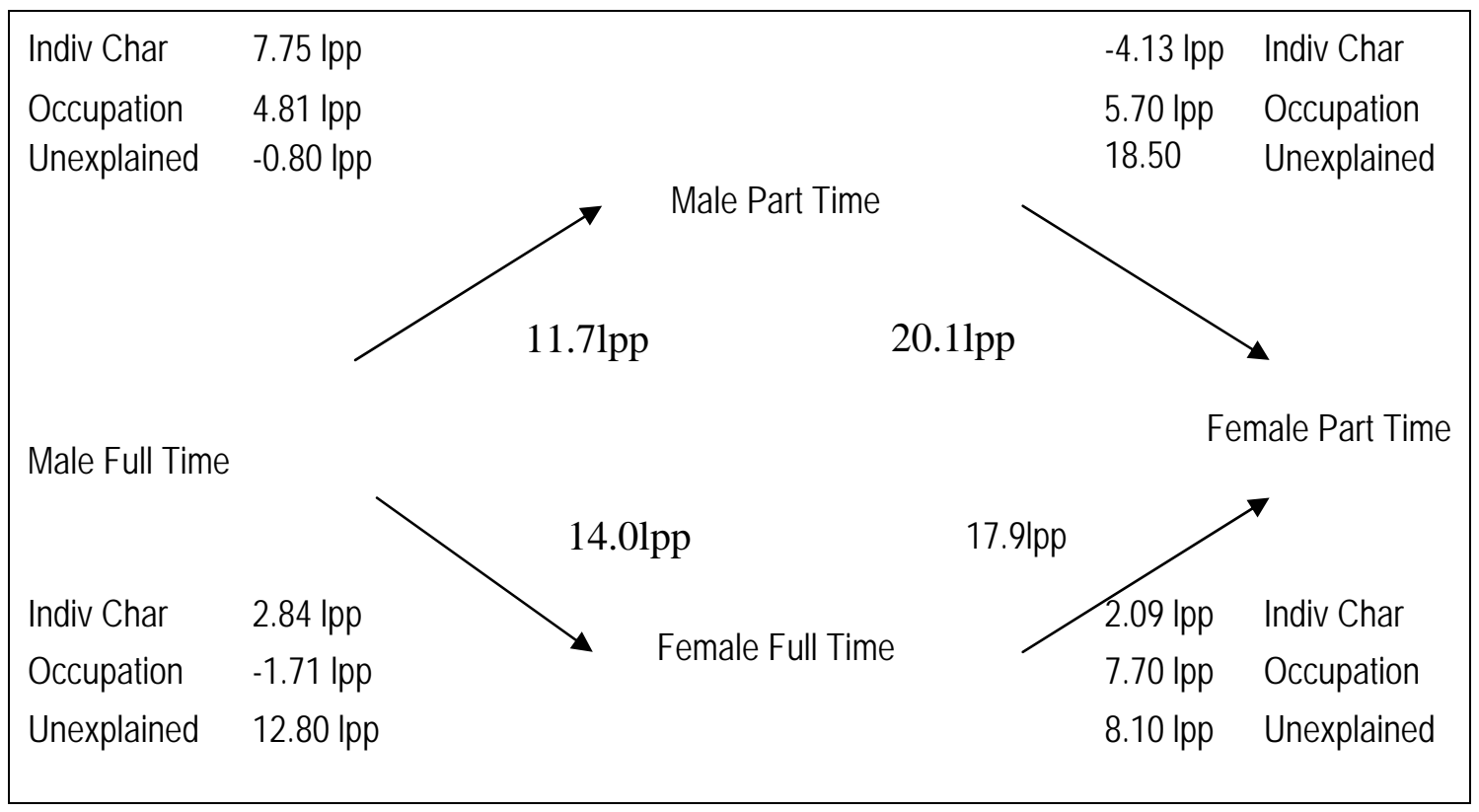

Notes: Each total bilateral earnings gap is presented next to an arrow indicating the direction of the comparison. In each case the contribution of each group of variables is evaluated using the parameters from the model for the higher earnings group. All figures are expressed in log-percentage points. 
Figure 4. Decompositions of the Earnings Gaps : Model D

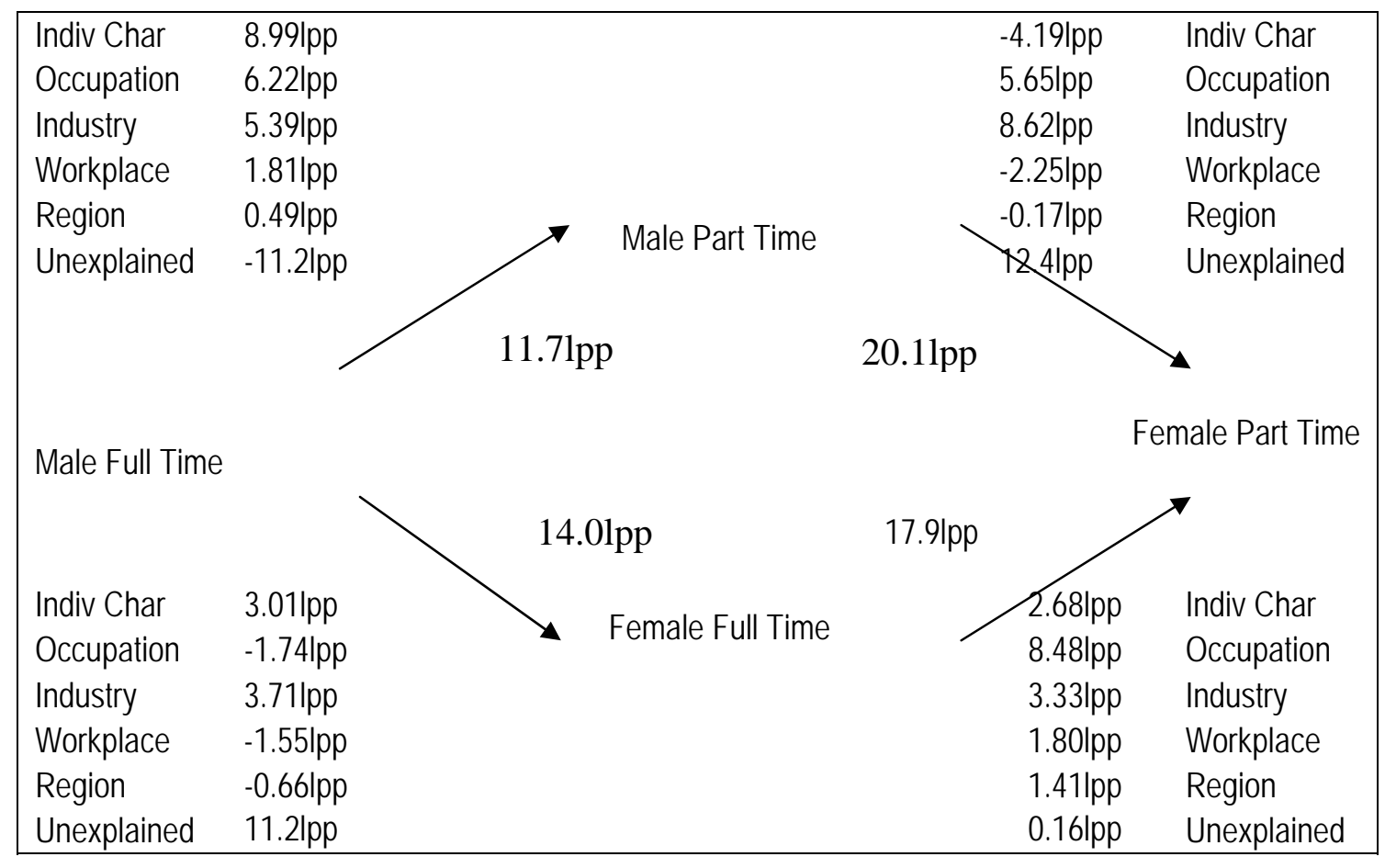

Notes:Each total bilateral earnings gap is presented next to an arrow indicating the direction of the comparison. In each case the contribution of each group of variables is evaluated using the parameters from the model for the higher earnings group. All figures are expressed in log-percentage points. 
Figure 5. Decompositions of the Earnings Gaps : Model E

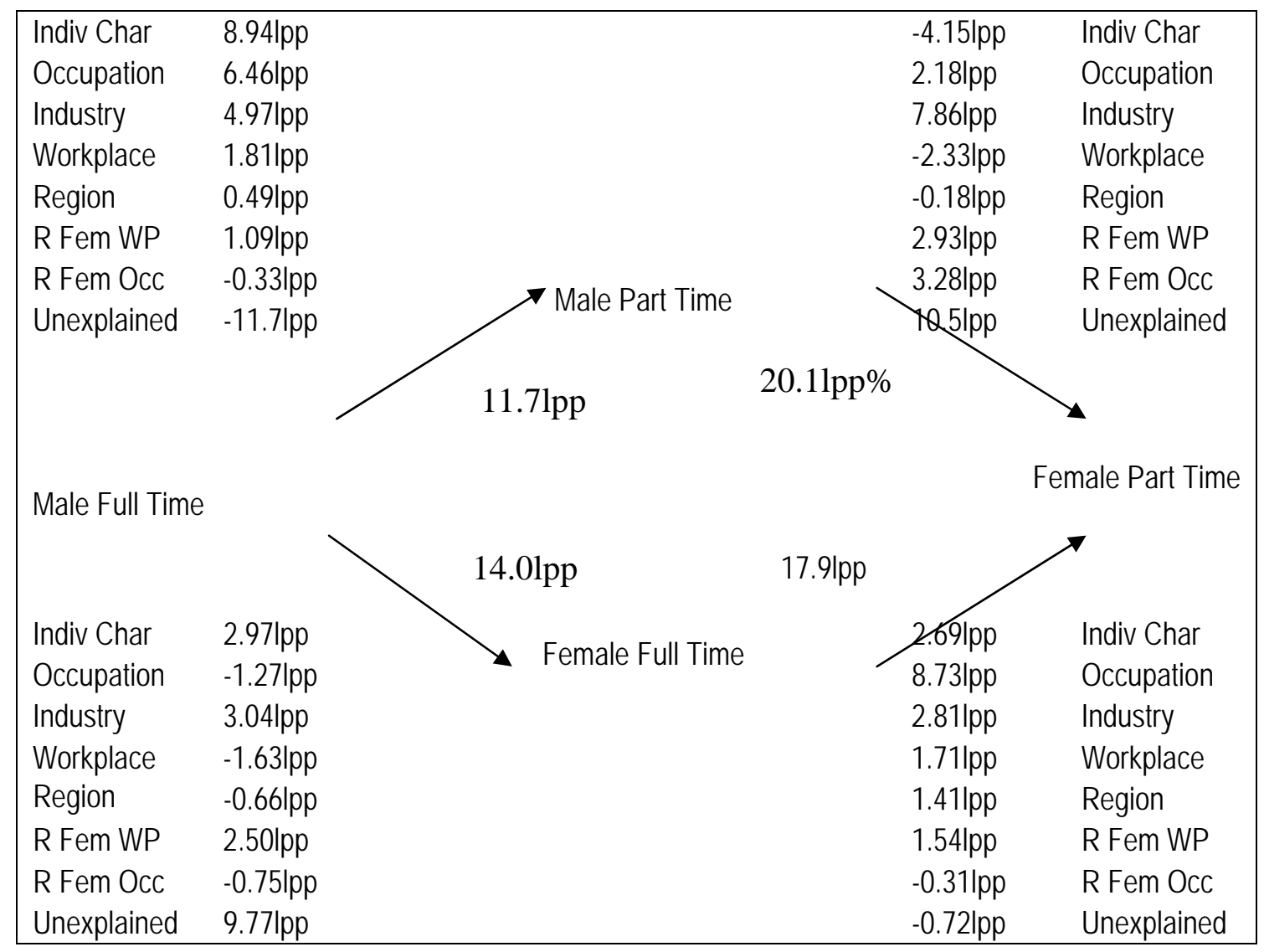

Notes: Each total bilateral earnings gap is presented next to an arrow indicating the direction of the comparison. In each case the contribution of each group of variables is evaluated using the parameters from the model for the higher earnings group. All figures are expressed in log-percentage points. 


\section{Appendix for:- Assessing the importance of male and female part-time work for the gender earning gap in Britain.}

By Karen Mumford* and Peter N. Smith $\dagger$

*Department of Economics and Related Studies, University of York, Heslington York YO10 5DD and IZA, Institute for the Study of Labour; e-mail: kam9@york.ac.uk

$\dagger$ Department of Economics and Related Studies, University of York, Heslington York YO10 5DD. 
Table A1. Variable definitions.

\begin{tabular}{|c|c|}
\hline Variable name & Variable definition \\
\hline hourly pay & Average hourly pay [midpoints of 14 bands]] \\
\hline log hourly pay & The natural log of average hourly pay \\
\hline \multicolumn{2}{|l|}{ Individual characteristics: } \\
\hline potential experience (years) & Age minus (approximate years of schooling plus 5), measured in years. \\
\hline training (days in previous year) & Days of training in the previous twelve months [midpoints of 6 bars, top coded at 10 days] \\
\hline \multicolumn{2}{|l|}{ education measures; } \\
\hline None/other & Has none of the academic qualifications listed (may have other academic qualifications than those listed) \\
\hline cse25 & Highest level of education is GCSE grades D-G; CSE grades 2-5 SCE; O grades D-; SCE Standard grades 4-7. \\
\hline cse1 & $\begin{array}{l}\text { Highest level of education is GCSE grades A-C; GCE O-level passes; CSE grade } 1 \text { SCE; O grades A-C; or SCE } \\
\text { Standard 1-3 }\end{array}$ \\
\hline gceae & Highest level of education is GCE A-level grades A-E; 1-2 SCE; Higher grades A-C, As levels \\
\hline gce2ae & Highest level of education is 2 or more GCE; A-levels grades A-E; 3 or more SCE; or Higher grades A-C \\
\hline degree & Highest level of education is a first degree, eg BSc, BA, HND, HNC Ma at first degree level \\
\hline postgrad & Highest level of education is a higher degree, eg MSc, MA, PGCE, PhD \\
\hline child & Has a dependent child aged below 18 \\
\hline child 0-4 & Youngest dependent child aged 0-4 \\
\hline child 5-11 & Youngest dependent child aged 5-11 \\
\hline child 12-18 & Youngest dependent child aged 12-18 \\
\hline married & Married or living with a partner \\
\hline disabled & Has a long term (>1 year) illness/disability \\
\hline ethnic & $\begin{array}{l}\text { Employee considers they are white and black Caribbean; white and black African; white and Asian; any other mixed } \\
\text { background; Indian; Pakistani; Bangladeshi; any other Asian background; Caribbean; African; any other black } \\
\text { background; Chinese; or any other ethnic group. }\end{array}$ \\
\hline fixed contract & Employed on a fixed term contract \\
\hline hours & Usual hours worked per week (includes over-time) \\
\hline part time & Working part time, if usual working hours is less than or equal to 30 per week \\
\hline tenure & Years at this workplace [midpoints of 5 bars, top coded at 10 years] \\
\hline
\end{tabular}




\begin{tabular}{|c|c|}
\hline Variable name & Variable definition \\
\hline union & Employee is a union member \\
\hline \multicolumn{2}{|l|}{ occupation categories; } \\
\hline managerial & Managerial \\
\hline professional & Professional \\
\hline technical & Technical \\
\hline clerical & Clerical \\
\hline craft & Craft service \\
\hline personal & Personal service \\
\hline sales & Sales and customer services \\
\hline operative & Operative and assembly workers \\
\hline unskilled & Unskilled \\
\hline \multicolumn{2}{|c|}{ Workplace characteristics: } \\
\hline workplace size & Total number of employees in the workplace \\
\hline workplace age & Establishment Age (/1000) \\
\hline multi site & Firm has multiple UK work sites \\
\hline foreign owned & Foreign controlled workplace \\
\hline increasing market & Market for workplace main product or service is growing \\
\hline age based wage & Pay Based on Age or Years of Experience \\
\hline grade based wage & Pay Based on Job Grade \\
\hline equal opportunity & Workplace has a formal written equal opportunity policy \\
\hline family friendly index & $\begin{array}{l}\text { Index of Six Family Friendly Policies available at the workplace: paternity leave; maternity leave; home } \\
\text { working; job sharing; child care; paid leave. }\end{array}$ \\
\hline paternity leave & If employees on paternity leave receives the normal, full rate of pay \\
\hline maternity leave & If employees on maternity leave receives the normal, full rate of pay \\
\hline home working & If employees can work at home \\
\hline job sharing & If a job sharing scheme exists in the workplace \\
\hline child care & If a workplace nursery or child care subsidy is available at the workplace \\
\hline paid leave & If paid family leave is available \\
\hline
\end{tabular}




\begin{tabular}{|c|c|}
\hline Variable name & Variable definition \\
\hline interaction index & $\begin{array}{l}\text { Index of five employee-employer interaction measures at the workplace: employee has a lot of discretion over work; } \\
\text { quality circles exists; team working exists; employees consulted over targets; employee briefing system exists }\end{array}$ \\
\hline IR index & $\begin{array}{l}\text { Index of three industrial relations measures at the workplace: union membership presence; human resources } \\
\text { representative; collective grievance procedure present }\end{array}$ \\
\hline rel female workplace & Proportion of females in the work place \\
\hline rel female occupation & Proportion of females in the occupation \\
\hline \multicolumn{2}{|l|}{ regions: } \\
\hline north east & north east of England \\
\hline north west & north west of England \\
\hline yorkshire \& the humberside & Yorkshire \& the Humberside \\
\hline east midlands & east midlands of England \\
\hline west midlands & west midlands of England \\
\hline east of england & east of England \\
\hline london & London \\
\hline south east & south east of England \\
\hline south west & south west of England \\
\hline scotland & Scotland \\
\hline wales & Wales \\
\hline
\end{tabular}

Source: WERS 2004. 
Table A2. Sample means for the aggregate samples.

\begin{tabular}{|c|c|c|c|c|c|c|c|c|c|c|}
\hline & \multicolumn{2}{|c|}{ Full sample } & \multicolumn{2}{|c|}{ All males } & \multicolumn{2}{|c|}{ All females } & \multicolumn{2}{|c|}{ Full-time } & \multicolumn{2}{|c|}{ Part-time } \\
\hline & mean & s.e. & mean & s.e. & mean & s.e. & mean & s.e. & mean & s.e. \\
\hline log hourly pay & 2.126 & 0.009 & 2.234 & 0.012 & 2.030 & 0.010 & 2.191 & 0.010 & 1.969 & 0.014 \\
\hline potential experience & 23.300 & 0.168 & 23.746 & 0.212 & 22.886 & 0.215 & 22.848 & 0.179 & 24.390 & 0.298 \\
\hline training & 2.560 & 0.041 & 2.592 & 0.056 & 2.533 & 0.047 & 2.810 & 0.049 & 1.954 & 0.052 \\
\hline \multicolumn{11}{|l|}{ education measures: } \\
\hline educ none/other & 0.229 & 0.005 & 0.254 & 0.007 & 0.207 & 0.006 & 0.217 & 0.005 & 0.257 & 0.008 \\
\hline cse25 & 0.096 & 0.003 & 0.102 & 0.004 & 0.091 & 0.004 & 0.098 & 0.003 & 0.091 & 0.005 \\
\hline cse1 & 0.257 & 0.005 & 0.216 & 0.006 & 0.294 & 0.006 & 0.247 & 0.005 & 0.282 & 0.008 \\
\hline ceae & 0.055 & 0.002 & 0.047 & 0.003 & 0.062 & 0.003 & 0.050 & 0.002 & 0.065 & 0.004 \\
\hline ce2ae & 0.091 & 0.003 & 0.086 & 0.004 & 0.096 & 0.004 & 0.084 & 0.003 & 0.108 & 0.006 \\
\hline degree & 0.193 & 0.005 & 0.210 & 0.007 & 0.179 & 0.005 & 0.218 & 0.006 & 0.134 & 0.006 \\
\hline postgraduate & 0.064 & 0.003 & 0.072 & 0.004 & 0.057 & 0.003 & 0.071 & 0.004 & 0.047 & 0.003 \\
\hline child 0-4 & 0.117 & 0.003 & 0.144 & 0.004 & 0.094 & 0.003 & 0.111 & 0.003 & 0.132 & 0.006 \\
\hline child 5-11 & 0.136 & 0.003 & 0.138 & 0.004 & 0.134 & 0.004 & 0.119 & 0.003 & 0.177 & 0.006 \\
\hline child 12-18 & 0.121 & 0.003 & 0.112 & 0.004 & 0.129 & 0.004 & 0.116 & 0.003 & 0.133 & 0.005 \\
\hline married & 0.668 & 0.005 & 0.394 & 0.006 & 0.357 & 0.006 & 0.662 & 0.005 & 0.681 & 0.009 \\
\hline disabled & 0.117 & 0.003 & 0.678 & 0.006 & 0.659 & 0.006 & 0.117 & 0.003 & 0.118 & 0.005 \\
\hline ethnic & 0.061 & 0.004 & 0.128 & 0.004 & 0.108 & 0.004 & 0.062 & 0.004 & 0.058 & 0.006 \\
\hline fixed contract & 0.030 & 0.002 & 0.066 & 0.005 & 0.057 & 0.004 & 0.029 & 0.002 & 0.035 & 0.003 \\
\hline part time & 0.293 & 0.006 & 0.029 & 0.002 & 0.031 & 0.002 & 0.000 & 0.000 & 1.000 & 0.000 \\
\hline tenure & 5.038 & 0.053 & 0.122 & 0.005 & 0.445 & 0.008 & 5.118 & 0.062 & 4.845 & 0.075 \\
\hline union & 0.314 & 0.008 & 5.262 & 0.071 & 4.836 & 0.062 & 0.327 & 0.009 & 0.285 & 0.010 \\
\hline female & 0.528 & 0.007 & 0.319 & 0.011 & 0.310 & 0.009 & 0.414 & 0.008 & 0.803 & 0.008 \\
\hline
\end{tabular}




\begin{tabular}{|c|c|c|c|c|c|c|c|c|c|c|}
\hline \multicolumn{11}{|l|}{ occupations: } \\
\hline Managerial & 0.120 & 0.004 & 0.159 & 0.006 & 0.085 & 0.004 & 0.148 & 0.005 & 0.052 & 0.004 \\
\hline Technical & 0.149 & 0.005 & 0.137 & 0.006 & 0.160 & 0.006 & 0.162 & 0.005 & 0.119 & 0.006 \\
\hline Clerical & 0.182 & 0.005 & 0.084 & 0.004 & 0.270 & 0.008 & 0.173 & 0.006 & 0.204 & 0.009 \\
\hline Craft & 0.072 & 0.004 & 0.138 & 0.008 & 0.013 & 0.002 & 0.091 & 0.005 & 0.026 & 0.003 \\
\hline Operative & 0.082 & 0.005 & 0.143 & 0.008 & 0.028 & 0.004 & 0.104 & 0.006 & 0.029 & 0.003 \\
\hline Unskilled & 0.119 & 0.005 & 0.137 & 0.008 & 0.102 & 0.006 & 0.095 & 0.006 & 0.177 & 0.010 \\
\hline \multicolumn{11}{|l|}{ industries: } \\
\hline Manufacturing & 0.163 & 0.007 & 0.255 & 0.011 & 0.081 & 0.006 & 0.208 & 0.008 & 0.053 & 0.004 \\
\hline Utilities & 0.004 & 0.001 & 0.005 & 0.001 & 0.003 & 0.001 & 0.004 & 0.001 & 0.002 & 0.001 \\
\hline Construction & 0.039 & 0.004 & 0.067 & 0.008 & 0.014 & 0.002 & 0.048 & 0.005 & 0.017 & 0.002 \\
\hline Whole/Retail & 0.148 & 0.007 & 0.136 & 0.009 & 0.159 & 0.009 & 0.123 & 0.008 & 0.210 & 0.011 \\
\hline Education & 0.091 & 0.004 & 0.048 & 0.003 & 0.129 & 0.006 & 0.066 & 0.004 & 0.151 & 0.008 \\
\hline Health & 0.144 & 0.007 & 0.060 & 0.005 & 0.219 & 0.010 & 0.113 & 0.007 & 0.217 & 0.011 \\
\hline Other Community & 0.047 & 0.004 & 0.047 & 0.006 & 0.046 & 0.004 & 0.042 & 0.004 & 0.059 & 0.006 \\
\hline workplace age & 43.957 & 1.636 & 44.852 & 1.952 & 43.166 & 1.769 & 44.050 & 1.743 & 43.732 & 2.072 \\
\hline workplace size (/1000) & 0.487 & 0.046 & 0.463 & 0.040 & 0.510 & 0.058 & 0.513 & 0.045 & 0.426 & 0.055 \\
\hline multi site & 0.755 & 0.012 & 0.732 & 0.016 & 0.776 & 0.013 & 0.753 & 0.014 & 0.761 & 0.015 \\
\hline foreign owned & 0.136 & 0.010 & 0.177 & 0.014 & 0.098 & 0.009 & 0.159 & 0.012 & 0.079 & 0.010 \\
\hline increasing market & 0.336 & 0.014 & 0.344 & 0.017 & 0.329 & 0.015 & 0.331 & 0.015 & 0.349 & 0.017 \\
\hline age based wage & 0.463 & 0.014 & 0.438 & 0.017 & 0.487 & 0.016 & 0.480 & 0.016 & 0.424 & 0.017 \\
\hline
\end{tabular}




\begin{tabular}{|c|c|c|c|c|c|c|c|c|c|c|}
\hline & \multicolumn{2}{|c|}{ Full sample } & \multicolumn{2}{|c|}{ All males } & \multicolumn{2}{|c|}{ All females } & \multicolumn{2}{|c|}{ Full-time } & \multicolumn{2}{|c|}{ Part-time } \\
\hline & mean & s.e. & mean & s.e. & mean & s.e. & mean & s.e. & mean & s.e. \\
\hline grade based wage & 0.263 & 0.013 & 0.252 & 0.015 & 0.273 & 0.014 & 0.283 & 0.015 & 0.215 & 0.013 \\
\hline family friendly index & 3.055 & 0.040 & 2.913 & 0.052 & 3.182 & 0.044 & 3.076 & 0.045 & 3.004 & 0.050 \\
\hline interaction index & 2.580 & 0.032 & 2.535 & 0.041 & 2.619 & 0.036 & 2.622 & 0.035 & 2.477 & 0.042 \\
\hline IR index & 1.218 & 0.024 & 1.204 & 0.030 & 1.231 & 0.028 & 1.225 & 0.027 & 1.201 & 0.030 \\
\hline equal opp & 0.858 & 0.009 & 0.837 & 0.013 & 0.877 & 0.010 & 0.862 & 0.010 & 0.850 & 0.013 \\
\hline rel female workplace & 0.526 & 0.739 & 0.336 & 0.761 & 0.696 & 0.553 & 0.455 & 0.795 & 0.698 & 0.746 \\
\hline $\begin{array}{l}\text { rel female occupation } \\
\text { regions: }\end{array}$ & 0.526 & 0.357 & 0.421 & 0.464 & 0.620 & 0.332 & 0.491 & 0.416 & 0.611 & 0.404 \\
\hline North East & 0.038 & 0.005 & 0.040 & 0.008 & 0.035 & 0.005 & 0.037 & 0.006 & 0.039 & 0.007 \\
\hline North West & 0.146 & 0.011 & 0.149 & 0.013 & 0.143 & 0.012 & 0.146 & 0.012 & 0.146 & 0.013 \\
\hline Yorkshire \& The Humber & 0.096 & 0.009 & 0.096 & 0.011 & 0.095 & 0.010 & 0.092 & 0.010 & 0.103 & 0.011 \\
\hline East Midlands & 0.069 & 0.008 & 0.072 & 0.009 & 0.066 & 0.009 & 0.070 & 0.008 & 0.066 & 0.009 \\
\hline West Midlands & 0.098 & 0.009 & 0.100 & 0.011 & 0.096 & 0.010 & 0.095 & 0.010 & 0.105 & 0.013 \\
\hline East Of England & 0.091 & 0.008 & 0.090 & 0.010 & 0.092 & 0.009 & 0.089 & 0.009 & 0.095 & 0.011 \\
\hline London & 0.102 & 0.008 & 0.100 & 0.010 & 0.104 & 0.009 & 0.112 & 0.010 & 0.078 & 0.008 \\
\hline South East & 0.129 & 0.010 & 0.123 & 0.012 & 0.135 & 0.011 & 0.131 & 0.011 & 0.126 & 0.012 \\
\hline South West & 0.082 & 0.008 & 0.079 & 0.009 & 0.085 & 0.009 & 0.081 & 0.008 & 0.086 & 0.010 \\
\hline Scotland & 0.112 & 0.010 & 0.114 & 0.012 & 0.109 & 0.010 & 0.111 & 0.010 & 0.114 & 0.012 \\
\hline Wales & 0.038 & 0.005 & 0.037 & 0.006 & 0.039 & 0.006 & 0.036 & 0.005 & 0.042 & 0.007 \\
\hline No. observations & & 21156 & & 9841 & & 11287 & & 15102 & & 6054 \\
\hline
\end{tabular}

Source: WERS 2004. 
Table A3. Model C, workplace effects; full and part time, male and female.

\begin{tabular}{|c|c|c|c|c|c|c|c|c|}
\hline \multirow[t]{2}{*}{ log hourly pay } & \multicolumn{2}{|c|}{ Male full-time } & \multicolumn{2}{|c|}{ Female full-time } & \multicolumn{2}{|c|}{ Male part-time } & \multicolumn{2}{|c|}{ Female part-time } \\
\hline & coeff & t-value & coeff & t-value & coeff & $\mathrm{t}$-value & coeff & $\mathrm{t}$-value \\
\hline potential experience & 0.023 & $13.42^{*}$ & 0.024 & $13.59^{\star}$ & 0.023 & $2.48 *$ & 0.014 & $4.14^{*}$ \\
\hline pot exp sqd (x1000) & -0.337 & $-10.55^{\star}$ & -0.417 & $-10.61^{*}$ & -0.571 & $-2.91^{*}$ & -0.274 & $-3.97^{\star}$ \\
\hline training & 0.002 & 1.43 & 0.005 & $2.79^{\star}$ & 0.016 & 1.62 & 0.013 & $3.27^{*}$ \\
\hline \multicolumn{9}{|c|}{ education none/other is omitted } \\
\hline $\operatorname{cse} 25$ & 0.067 & $4.72^{*}$ & 0.063 & $3.26^{*}$ & 0.130 & 1.09 & 0.045 & 1.52 \\
\hline cse1 & 0.094 & $7.74^{*}$ & 0.107 & $6.55^{\star}$ & 0.121 & 0.94 & 0.026 & 1.11 \\
\hline ceae & 0.124 & $6.73^{*}$ & 0.144 & $5.91^{*}$ & 0.173 & 1.01 & 0.034 & 0.89 \\
\hline ce2ae & 0.201 & $11.65^{\star}$ & 0.163 & $7.62^{\star}$ & 0.287 & $2.00^{*}$ & 0.124 & $3.15^{*}$ \\
\hline degree & 0.241 & $15.67^{*}$ & 0.272 & $12.58^{\star}$ & 0.217 & 1.60 & 0.251 & $5.98^{*}$ \\
\hline postgrad & 0.358 & $16.04^{*}$ & 0.351 & $12.26^{\star}$ & 0.133 & 0.91 & 0.217 & $4.35^{*}$ \\
\hline child 0-4 & 0.039 & $3.66^{\star}$ & -0.002 & -0.12 & -0.107 & -0.73 & -0.056 & -1.81 \\
\hline child 5-11 & 0.035 & $2.83^{*}$ & -0.006 & -0.37 & -0.244 & $-2.03^{*}$ & -0.056 & $-2.16^{\star}$ \\
\hline child $12-18$ & 0.032 & $2.70^{*}$ & -0.043 & $-2.78^{*}$ & -0.073 & -0.55 & -0.056 & $-2.35^{\star}$ \\
\hline married & 0.059 & $5.92^{*}$ & 0.031 & $3.36^{\star}$ & 0.140 & 1.85 & 0.002 & 0.10 \\
\hline disabled & -0.015 & -1.32 & -0.028 & -1.75 & -0.113 & -1.47 & -0.032 & -1.33 \\
\hline ethnic & -0.052 & $-2.70^{\star}$ & -0.077 & $-2.98^{*}$ & -0.002 & -0.02 & -0.110 & $-2.43^{\star}$ \\
\hline fixed contract & -0.077 & $-2.42^{\star}$ & -0.096 & $-2.91^{*}$ & 0.078 & 0.47 & 0.034 & 0.85 \\
\hline tenure & 0.011 & $8.07^{*}$ & 0.013 & $8.25^{*}$ & 0.030 & $1.99 *$ & 0.011 & $4.12^{*}$ \\
\hline union & -0.013 & -1.05 & 0.028 & $2.40^{\star}$ & 0.024 & 0.28 & 0.080 & $3.45^{*}$ \\
\hline $\begin{array}{c}\text { clerical is omitted } \\
\text { managerial }\end{array}$ & & & & & & & & \\
\hline $\begin{array}{l}\text { managerial } \\
\text { professional }\end{array}$ & $\begin{array}{l}0.261 \\
0.172\end{array}$ & $\begin{array}{l}13.15^{*} \\
736^{*}\end{array}$ & $\begin{array}{l}0.315 \\
0.321\end{array}$ & $\begin{array}{l}17.37^{*} \\
13.11^{*}\end{array}$ & $\begin{array}{l}0.653 \\
0.425\end{array}$ & $\begin{array}{l}3.64^{*} \\
2.32^{*}\end{array}$ & $\begin{array}{l}0.394 \\
0.565\end{array}$ & $\begin{array}{l}5.07^{*} \\
1146^{*}\end{array}$ \\
\hline technical & 0.098 & $5.04^{*}$ & 0.176 & $\begin{array}{l}10.11 \\
11.70^{*}\end{array}$ & 0.246 & $\begin{array}{l}2.02 \\
1.59\end{array}$ & 0.225 & $\begin{array}{l}11.40 \\
6.28^{*}\end{array}$ \\
\hline craft & -0.010 & -0.51 & -0.079 & -1.51 & 0.187 & 0.89 & -0.115 & -1.33 \\
\hline personal & -0.091 & $-2.70^{\star}$ & -0.112 & $-4.76^{*}$ & 0.033 & 0.19 & -0.120 & $-3.49^{\star}$ \\
\hline sales & -0.088 & $-3.20^{*}$ & -0.034 & -1.34 & -0.075 & -0.52 & -0.047 & -0.96 \\
\hline operative & -0.150 & $-7.13^{\star}$ & -0.127 & $-4.27^{*}$ & -0.102 & -0.43 & -0.290 & $-2.60^{\star}$ \\
\hline unskilled & -0.235 & $-9.85^{\star}$ & -0.166 & $-5.57^{*}$ & -0.042 & -0.28 & -0.216 & $-5.80^{\star}$ \\
\hline constant & 1.689 & $61.10^{*}$ & 1.536 & $62.67^{\star}$ & 1.584 & $8.72^{\star}$ & 1.634 & $31.99 *$ \\
\hline No. observations & & 8661 & & 6424 & & 1180 & & 4863 \\
\hline R-squared & & 0.754 & & 0.743 & & 0.865 & & 0.662 \\
\hline Adj R-squared & & 0.753 & & 0.742 & & 0.862 & & 0.661 \\
\hline MSE & & 0.255 & & 0.256 & & 0.542 & & 0.418 \\
\hline
\end{tabular}

Source: WERS 2004. *significant at a 95\% confidence level or above. 
Table A4. Model E, weighted OLS; full and part time, male and female.

\begin{tabular}{|c|c|c|c|c|c|c|c|c|}
\hline \multirow[t]{2}{*}{ log hourly pay } & \multicolumn{2}{|c|}{ Male full-time } & \multicolumn{2}{|c|}{ Female full-time } & \multicolumn{2}{|c|}{ Male part-time } & \multicolumn{2}{|c|}{ Female part-time } \\
\hline & coeff & t-value & coeff & t-value & coeff & t-value & coeff & t-value \\
\hline potential experience & 0.025 & $15.26^{*}$ & 0.027 & $14.37^{*}$ & 0.011 & 1.54 & 0.020 & $5.91^{*}$ \\
\hline pot exp sqd (x1000) & -0.371 & $-11.47^{\star}$ & -0.471 & $-11.68^{*}$ & -0.239 & -1.68 & -0.413 & $-5.91^{*}$ \\
\hline training & 0.004 & $2.63^{*}$ & 0.007 & $4.55^{\star}$ & 0.019 & $2.81 *$ & 0.011 & $3.15^{\star}$ \\
\hline \multicolumn{9}{|c|}{ education none/other is omitted } \\
\hline cse25 & 0.081 & $5.48^{*}$ & 0.071 & $3.39 *$ & 0.172 & 1.79 & -0.016 & -0.54 \\
\hline cse1 & 0.125 & $9.24^{*}$ & 0.128 & $8.16^{*}$ & 0.135 & 1.63 & 0.018 & 0.75 \\
\hline ceae & 0.133 & $5.91^{*}$ & 0.161 & $5.93^{\star}$ & 0.185 & 1.49 & 0.022 & 0.61 \\
\hline ce2ae & 0.238 & $12.63^{*}$ & 0.192 & $9.05^{\star}$ & 0.259 & $2.90 *$ & 0.153 & $3.54^{*}$ \\
\hline degree & 0.314 & $19.28^{*}$ & 0.327 & $16.13^{*}$ & 0.272 & $3.10^{*}$ & 0.206 & $5.40^{\star}$ \\
\hline postgrad & 0.439 & $19.66^{*}$ & 0.387 & $15.93^{*}$ & 0.342 & $3.35^{*}$ & 0.204 & $4.45^{\star}$ \\
\hline child 0-4 & 0.056 & $4.86^{\star}$ & 0.037 & 1.91 & -0.083 & -0.97 & -0.072 & $-2.50^{*}$ \\
\hline child 5-11 & 0.045 & $3.43^{\star}$ & -0.016 & -0.88 & 0.032 & 0.37 & -0.107 & $-3.66^{*}$ \\
\hline child 12-18 & 0.030 & $2.21 *$ & -0.058 & $-3.63^{*}$ & 0.151 & 1.59 & -0.084 & $-3.27^{*}$ \\
\hline married & 0.069 & $6.63^{*}$ & 0.023 & $2.39 *$ & 0.028 & 0.45 & 0.030 & 1.44 \\
\hline disabled & -0.021 & -1.76 & -0.043 & $-2.73^{*}$ & -0.172 & $-3.17^{\star}$ & -0.014 & -0.49 \\
\hline ethnic & -0.074 & $-3.70^{*}$ & -0.109 & $-4.96^{*}$ & -0.111 & -1.53 & -0.100 & $-2.40^{*}$ \\
\hline fixed contract & -0.023 & -0.65 & -0.061 & $-2.08^{*}$ & 0.060 & 0.72 & 0.033 & 0.80 \\
\hline tenure & 0.012 & $8.20^{*}$ & 0.010 & $6.48^{\star}$ & 0.017 & $1.98^{*}$ & 0.008 & $3.08^{\star}$ \\
\hline union & 0.017 & 1.23 & 0.022 & 1.88 & 0.150 & $2.78^{*}$ & 0.097 & $4.66^{*}$ \\
\hline \multicolumn{9}{|l|}{ clerical is omitted } \\
\hline managerial & 0.274 & $18.71^{*}$ & 0.291 & $9.71^{*}$ & 0.508 & $4.76^{*}$ & 0.591 & $6.53^{\star}$ \\
\hline professional & 0.228 & $11.38 *$ & 0.339 & $12.96^{*}$ & 0.379 & $3.64^{*}$ & 0.626 & $11.10^{*}$ \\
\hline technical & 0.146 & $8.17^{*}$ & 0.187 & $10.61^{*}$ & 0.217 & $2.08^{*}$ & 0.349 & $8.47^{*}$ \\
\hline personal & -0.120 & $-3.87^{*}$ & -0.173 & $-7.98 *$ & -0.064 & -0.57 & -0.179 & $-6.33^{*}$ \\
\hline sales & -0.164 & $-5.52^{*}$ & -0.070 & $-2.97^{\star}$ & -0.309 & $-3.01^{*}$ & -0.126 & $-3.45^{*}$ \\
\hline operative & -0.141 & $-7.67^{*}$ & -0.111 & $-2.59 *$ & -0.279 & $-2.12^{\star}$ & 0.072 & 0.56 \\
\hline unskilled & -0.264 & $-12.58^{\star}$ & -0.192 & $-6.55^{\star}$ & -0.320 & $-3.54^{*}$ & -0.182 & $-3.86^{*}$ \\
\hline \multicolumn{9}{|c|}{ manufacturing is omitted } \\
\hline utilities & 0.120 & $2.33^{*}$ & 0.144 & $3.28^{\star}$ & 0.328 & 1.06 & -0.059 & -0.69 \\
\hline construction & 0.049 & 1.84 & -0.008 & -0.12 & -0.014 & -0.08 & 0.195 & 1.28 \\
\hline whole/retail & -0.087 & $-3.24^{*}$ & -0.090 & $-2.90^{*}$ & -0.609 & $-4.46^{\star}$ & -0.281 & $-3.96^{*}$ \\
\hline hotels & -0.271 & $-6.40^{*}$ & -0.175 & $-5.73^{\star}$ & -0.847 & $-5.10^{\star}$ & -0.282 & $-4.03^{*}$ \\
\hline transport & 0.015 & 0.55 & 0.080 & $2.47^{\star}$ & -0.152 & -1.14 & -0.011 & -0.13 \\
\hline financial services & 0.063 & $2.11^{*}$ & 0.093 & $3.53^{*}$ & -0.413 & $-2.39 *$ & 0.003 & 0.04 \\
\hline other business & 0.024 & 0.94 & 0.086 & $3.39 *$ & -0.418 & $-3.15^{\star}$ & -0.038 & -0.50 \\
\hline public admin & -0.057 & -1.92 & 0.038 & 1.51 & -0.191 & -1.00 & -0.067 & -0.94 \\
\hline education & -0.181 & $-5.68 *$ & -0.057 & $-2.02^{*}$ & -0.643 & $-4.45^{\star}$ & -0.208 & $-2.89 *$ \\
\hline health & -0.107 & $-4.02^{*}$ & 0.007 & 0.25 & -0.582 & $-4.28^{\star}$ & -0.152 & $-2.16^{*}$ \\
\hline other community & -0.090 & $-2.92^{*}$ & 0.006 & 0.16 & -0.533 & $-3.60^{\star}$ & -0.249 & $-3.18^{*}$ \\
\hline workplace age & 0.000 & 0.11 & 0.000 & 0.96 & 0.000 & 0.66 & 0.000 & 0.70 \\
\hline workplace size & 0.013 & $2.05^{\star}$ & 0.012 & $2.90 *$ & -0.007 & -0.28 & 0.010 & 1.24 \\
\hline multi site & 0.002 & 0.14 & 0.010 & 0.64 & 0.068 & 1.09 & -0.017 & -0.61 \\
\hline foreign owned & 0.042 & $2.45^{\star}$ & 0.049 & $2.39 *$ & -0.066 & -0.76 & -0.004 & -0.09 \\
\hline increasing market & -0.034 & $-2.48^{*}$ & -0.027 & -1.94 & -0.079 & -1.54 & 0.020 & 0.88 \\
\hline age based wage & 0.029 & $2.06^{*}$ & 0.017 & 1.23 & 0.034 & 0.62 & 0.000 & -0.01 \\
\hline grade based wage & 0.032 & $1.96^{*}$ & 0.018 & 1.33 & 0.137 & $2.11^{*}$ & 0.013 & 0.54 \\
\hline family friendly index & 0.027 & $5.19^{*}$ & 0.029 & $6.40^{*}$ & 0.003 & 0.16 & 0.014 & 1.83 \\
\hline interaction index & 0.018 & $2.91^{*}$ & 0.016 & $2.78^{*}$ & 0.034 & 1.40 & 0.018 & 1.82 \\
\hline IR index & -0.001 & -0.07 & -0.016 & $-2.00^{*}$ & -0.023 & -0.74 & -0.004 & -0.35 \\
\hline equal opp & 0.019 & 0.87 & -0.006 & -0.26 & 0.063 & 0.71 & 0.009 & 0.26 \\
\hline rel fem workplace & -0.076 & $-2.31^{*}$ & -0.142 & $-5.01^{*}$ & -0.0997 & -0.99 & -0.208 & $-4.12^{*}$ \\
\hline
\end{tabular}




\begin{tabular}{|c|c|c|c|c|c|c|c|c|}
\hline & \multicolumn{2}{|c|}{ Male full-time } & \multicolumn{2}{|c|}{ Female full-time } & \multicolumn{2}{|c|}{ Male part-time } & \multicolumn{2}{|c|}{ Female part-time } \\
\hline & coeff & t-value & coeff & t-value & coeff & t-value & coeff & t-value \\
\hline rel fem occupation & 0.039 & 1.25 & 0.091 & 1.60 & -0.230 & -1.06 & 0.350 & $2.70^{*}$ \\
\hline \multicolumn{9}{|c|}{ east midlands is omitted } \\
\hline north east & -0.007 & -0.18 & -0.090 & $-2.23^{*}$ & 0.053 & 0.43 & 0.068 & 1.17 \\
\hline $\begin{array}{l}\text { north west } \\
\text { yorkshire \& the }\end{array}$ & -0.029 & -0.96 & -0.050 & -1.51 & -0.047 & -0.55 & 0.012 & 0.30 \\
\hline humber & 0.013 & 0.43 & -0.015 & -0.43 & -0.109 & -1.16 & 0.038 & 0.85 \\
\hline west midlands & 0.028 & 0.94 & -0.041 & -1.22 & -0.008 & -0.08 & 0.008 & 0.20 \\
\hline east of england & 0.082 & $2.51^{*}$ & 0.027 & 0.80 & 0.139 & 1.17 & 0.095 & $2.03^{*}$ \\
\hline Iondon & 0.211 & $6.73^{*}$ & 0.231 & $6.86^{*}$ & 0.163 & 1.73 & 0.320 & $6.87^{\star}$ \\
\hline south east & 0.118 & $4.22^{\star}$ & 0.087 & $2.62^{*}$ & 0.102 & 0.95 & 0.098 & $2.51^{*}$ \\
\hline south west & 0.015 & 0.47 & 0.005 & 0.13 & -0.102 & -0.98 & 0.020 & 0.44 \\
\hline scotland & -0.004 & -0.12 & 0.007 & 0.21 & -0.039 & -0.40 & 0.096 & $2.42^{\star}$ \\
\hline wales & -0.007 & -0.16 & -0.080 & $-2.10^{\star}$ & -0.162 & -1.52 & 0.097 & 1.93 \\
\hline constant & 1.412 & $30.94^{*}$ & 1.358 & $21.15^{\star}$ & 2.219 & $8.70^{*}$ & 1.544 & $13.07^{*}$ \\
\hline strata & & 89 & & 89 & & 84 & & 86 \\
\hline PSUs & & 1424 & & 1445 & & 750 & & 1254 \\
\hline No. observations & & 8661 & & 6424 & & 1180 & & 4863 \\
\hline Degrees freedom & & 1335 & & 1356 & & 666 & & 1168 \\
\hline R-squared & & 0.587 & & 0.571 & & 0.451 & & 0.431 \\
\hline
\end{tabular}

Source: WERS 2004. *significant at a 95\% confidence level or above. 